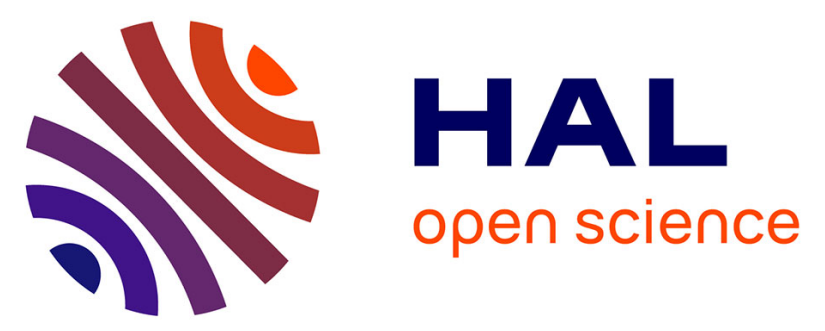

\title{
Hexamolybdenum Clusters Supported on Graphene Oxide: Visible-Light Induced Photocatalytic Reduction of Carbon Dioxide into Methanol
}

Pawan Kumar, Harshal P. Mungse, Stéphane Cordier, Rabah Boukherroub, Om P. Khatri, Suman L Jain

\section{To cite this version:}

Pawan Kumar, Harshal P. Mungse, Stéphane Cordier, Rabah Boukherroub, Om P. Khatri, et al.. Hexamolybdenum Clusters Supported on Graphene Oxide: Visible-Light Induced Photocatalytic Reduction of Carbon Dioxide into Methanol. Carbon, 2015, 94, pp.91-100. 10.1016/j.carbon.2015.06.029 . hal-01166772

HAL Id: hal-01166772

https://hal-univ-rennes1.archives-ouvertes.fr/hal-01166772

Submitted on 19 Nov 2015

HAL is a multi-disciplinary open access archive for the deposit and dissemination of scientific research documents, whether they are published or not. The documents may come from teaching and research institutions in France or abroad, or from public or private research centers.
L'archive ouverte pluridisciplinaire HAL, est destinée au dépôt et à la diffusion de documents scientifiques de niveau recherche, publiés ou non, émanant des établissements d'enseignement et de recherche français ou étrangers, des laboratoires publics ou privés. 


\section{Hexamolybdenum Clusters Supported on Graphene Oxide: Visible-Light Induced}

\section{Photocatalytic Reduction of Carbon Dioxide into Methanol}

Pawan Kumar, ${ }^{\text {a }}$ Harshal P. Mungse, ${ }^{\text {a }}$ Stéphane Cordier, ${ }^{\mathrm{b}}$ Rabah Boukherroub ${ }^{\mathrm{c}}$ Om P. Khatri, ${ }^{\mathrm{a}}$ and Suman L. Jain $*^{\mathrm{a}}$

${ }^{\mathrm{a}}$ Chemical Sciences Division, CSIR-Indian Institute of Petroleum, Dehradun 248005, India

${ }^{\mathrm{b}}$ Institut des Sciences Chimiques de Rennes, UMR 6226 UR1-CNRS, Université de Rennes 1, Campus de Beaulieu, 35042 Rennes Cedex, France

${ }^{\mathrm{c}}$ Institut d'Electronique, de Microélectronique et de Nanotechnologie (IEMN), UMR CNRS 8520, Université Lille1, Avenue Poincaré - BP 60069, 59652 Villeneuve d'Ascq, France

$$
\text { Email : sumanjain@iip.res.in }
$$

Abstract: Hexamolybdenum $\left(\mathrm{Mo}_{6}\right)$ cluster-based compounds namely $\mathrm{Cs}_{2} \mathrm{Mo}_{6} \mathrm{Br}_{8}{ }_{8}{ }^{\mathrm{a}}{ }_{6}$ and $\left(\mathrm{TBA}_{2} \mathrm{Mo}_{6} \mathrm{Br}_{8}^{\mathrm{i}} \mathrm{Br}_{6}^{\mathrm{a}}\right.$ $(\mathrm{TBA}=$ tetrabutylammonium $)$ were immobilized on graphene oxide (GO) nanosheets by taking advantage of the high lability of the apical bromide ions with oxygen-functionalities of GO nanosheets. The loading of $\mathrm{Mo}_{6}$ clusters on GO nanosheets was probed by Fourier-transform infrared (FTIR) spectroscopy, X-ray photoelectron spectroscopy (XPS), high resolution transmission electron microscopy (HRTEM) and elemental mapping analyses. The developed GO-Cs $\mathrm{MO}_{6} \mathrm{Br}_{8}^{\mathrm{i}} \mathrm{Br}^{\mathrm{a}}{ }_{\mathrm{x}}$ and GO-(TBA $)_{2} \mathrm{Mo}_{6} \mathrm{Br}_{8}^{\mathrm{i}} \mathrm{Br}^{\mathrm{a}}{ }_{x}$ composites were then used as heterogeneous photocatalysts for the reduction of $\mathrm{CO}_{2}$ under visible light irradiation. After $24 \mathrm{~h}$ visible light illumination, the yield of methanol was found to be 1644 and $1294 \mu$ mol.g ${ }^{-1}$ cat for GO-Cs ${ }_{2} \mathrm{Mo}_{6} \mathrm{Br}_{8}^{\mathrm{i}} \mathrm{Br}^{\mathrm{a}}{ }_{\mathrm{x}}$ and GO-(TBA $)_{2} \mathrm{Mo}_{6} \mathrm{Br}_{8}^{\mathrm{i}} \mathrm{Br}^{\mathrm{a}}{ }_{x}$, respectively. The quantum yields of methanol by using GO-Cs ${ }_{2} \mathrm{Mo}_{6} \mathrm{Br}_{8}{ }_{8} \mathrm{Br}^{\mathrm{a}}{ }_{x}$ and GO(TBA $)_{2} \mathrm{Mo}_{6} \mathrm{Br}_{8}^{\mathrm{i}} \mathrm{Br}^{\mathrm{a}} \times$ as catalysts with reference to $\mathrm{Mo}_{6}$ cluster units presented in $0.1 \mathrm{~g}$ amount of catalyst were found to be 0.015 and 0.011 , respectively. The role of immobilized $\mathrm{Mo}_{6}$ clusters-based compounds on GO nanosheets is discussed to understand the photocatalytic mechanism of $\mathrm{CO}_{2}$ reduction into methanol.

Keywords: Graphene oxide;Mo cluster compound; photocatalysis; carbon dioxide reduction; methanol. 


\subsection{Introduction}

Graphene oxide (GO), an oxidized form of graphene, conventionally served as a most established precursor for the preparation of reduced graphene oxide, chemically functionalized graphene and graphene-based composites [1-2]. Owing to its rich surface chemistry, high specific surface area and various structural defects, GO has attracted large attention not only as a catalytic material, but also as an excellent nanostructured support for heterogenization of various catalysts for efficient chemical transformations [3-4]. The first report on the catalytic activity of GO was revealed by Bielawski et al. in 2010 for the oxidation of various alcohols and the hydration of various alkynes [5]. Then after, the catalytic performance of $\mathrm{GO}$ was expanded for various chemical transformations, including oxidation of thiols, sulphides and olefins, aza-Michael addition of amines to activated alkenes, acetalization of aldehydes, ring-opening polymerization of various cyclic lactones and lactams, Friedel-Crafts addition of indoles to $\alpha, \beta$-unsaturated ketones, oxidative coupling of amines to imines, oxidative amidation of aromatic aldehydes, etc [6-11]. The catalytic properties of GO have mainly originated from the presence of various oxygen functionalities and unpaired electrons in the GO scaffold and its very high surface area [2-3]. Recently, Riedo et al have demonstrated that GO is a metastable material, whose structure and chemical functionalities evolve at room temperature [12]. Furthermore, an increase of temperature induces gradual reduction of oxygen functionalities in the GO [13]. The ease of GO aging and reduction during catalytic reactions under mild to high temperature raised the issue of recyclability of GO for chemical transformations [14].

Moreover, the high specific surface area, excellent dispersibility in water/ polar solvents, presence of plenty of oxygen containing functional groups and several structural defects in GO scaffold provide ample opportunities to serve as a nano-structured support for heterogenization of catalytically active metal complexes, organic functionalities, and transition metal clusters for efficient chemical transformations [15-19]. In recent years, several methodologies have been established for immobilization of various nano-materials on the GO nanosheets, which include the use of bi-functional linkers, light-induced immobilization, co-reduction of metal salts in the presence of GO, etc [2,20-22]. In most of these approaches, the oxygen functionalities and 
structural defects in the GO scaffold function as anchoring sites for the immobilization of various types of nanomaterials.

Molybdenum octahedral $\left(\mathrm{Mo}_{6}\right)$ clusters with the general formula $\mathrm{A}_{2} \mathrm{Mo}_{6} \mathrm{X}_{8}^{\mathrm{i}} \mathrm{X}_{6}^{\mathrm{a}}\left(\mathrm{A}=\mathrm{Cs}^{+}, n-\left(\mathrm{C}_{4} \mathrm{H}_{9}\right)_{4} \mathrm{~N}^{+}\right.$ and $\mathrm{X}=\mathrm{Br}^{-}$) exhibit photochemical and redox properties due to delocalization of valence electrons on the metal centers [23-25]. The $\mathrm{Mo}_{6}$ clusters are face-capped by eight inner ligands $\left(\mathrm{Br}^{\mathrm{i}}\right)$ through $\mathrm{Mo}-\mathrm{Br}^{\mathrm{i}}$ bonds having covalent dominant character, and are additionally bonded to six apical ligands $\left(\mathrm{Br}^{\mathrm{a}}\right)$ through $\mathrm{Mo}-\mathrm{Br}^{\mathrm{a}}$ linkage having strong ionic character. The dissolution of these clusters affords $\left[\mathrm{Mo}_{6} \mathrm{Br}_{8}{ }_{8} \mathrm{Br}_{6}^{\mathrm{a}}\right]^{2-}$ anionic units, where the $\mathrm{Mo}_{6} \mathrm{Br}_{8}^{\mathrm{i}}$ core constitutes a rigid block that can be functionalized by exchange/ replacement of $\mathrm{Br}^{\mathrm{a}}$ located at the apical position of the cluster. Owing to their remarkable structural and photo-physical properties, $\mathrm{A}_{2} \mathrm{Mo}_{6} \mathrm{X}_{8}^{\mathrm{i}} \mathrm{X}_{6}^{\mathrm{a}}$ cluster-based compounds provide immense potential for nanoarchitectonic and photocatalytic applications [26]. Recently, Boukherroub et al. have demonstrated that nanocomposites of $\mathrm{Mo}_{6}$ clusters, gold nanoparticles and GO exhibited very high photocatalytic activity for the degradation of rhodamine B under visible light irradiation. In these photocatalysts, the $\mathrm{Mo}_{6}$ cluster absorbs the incident photons and initiates the photocatalytic process [24]. The $\mathrm{Mo}_{6}$ clusters as homogeneous catalyst could also afford photo-reduction of $\mathrm{CO}_{2}$ into methanol induced by visible light. However, the need of sacrificial donor and non-recyclability of these clusters make the catalytic process expensive [27].

Due to the rising concentration of $\mathrm{CO}_{2}$ and the depletion of fossil fuel reserves, there is considerable interest in the development of alternative energy sources [28-30]. Conversion of $\mathrm{CO}_{2}$ into hydrocarbon fuels utilizing the abundant solar energy can provide a viable solution for both problems simultaneously [31-32]. In this regard, a number of heterogeneous catalysts including metal oxides, sulphides, nitrides and oxynitrides have been investigated for $\mathrm{CO}_{2}$ reduction, albeit lower quantum yields and poor selectivities are the major drawbacks [33-35]. Molecular catalysis, particularly, based on transition metal complexes, such as rhenium(I) bipyridine, ruthenium(II) polypyridine carbonyl, cobalt (II) trisbipyridine, and cobalt (III) macrocycles in combination with a photosensitizer have been considered to be high performance photocatalysts for $\mathrm{CO}_{2}$ reduction with relatively high quantum yield and high selectivity of products [36-39]. However, the homogeneous nature and non-recycling ability of these catalysts make them impractical from economical as well as environmental viewpoints. This problem can be overcome by anchoring these complexes to photoactive supports, which not 
only provides facile recovery of the catalyst, but also photoactive support and complex may work synergistically for better electron transfer to $\mathrm{CO}_{2}$ [40-41]. In a recent report, we have demonstrated the photocatalytic activity of $\mathrm{Mo}_{6}$ clusters for the photoreduction of $\mathrm{CO}_{2}$ using triethylamine as the sacrificial agent [27]. However, non-recycling ability of the photocatalyst and need of sacrificial donor (triethylamine) are the major drawbacks of the developed method. Herein, $\mathrm{Cs}_{2} \mathrm{Mo}_{6} \mathrm{Br}_{8}^{\mathrm{i}} \mathrm{Br}_{6}^{\mathrm{a}}$ and $(\mathrm{TBA})_{2} \mathrm{Mo}_{6} \mathrm{Br}_{8}^{\mathrm{i}} \mathrm{Br}_{6}^{\mathrm{a}}$ clusterbased compounds are systematically immobilized on GO nanosheets by taking advantage of labile nature of the apical bromide ions and oxygen-functionalities of GO nanosheets. The developed GO-C $\mathrm{C}_{2} \mathrm{Mo}_{6} \mathrm{Br}_{8}^{\mathrm{i}} \mathrm{Br}^{\mathrm{a}}{ }_{\mathrm{x}}$ and GO-(TBA $)_{2} \mathrm{Mo}_{6} \mathrm{Br}_{8}^{\mathrm{i}} \mathrm{Br}^{\mathrm{a}}{ }_{x}$ composites were then used as heterogeneous photocatalysts for the reduction of $\mathrm{CO}_{2}$ into methanol (Figure 1).

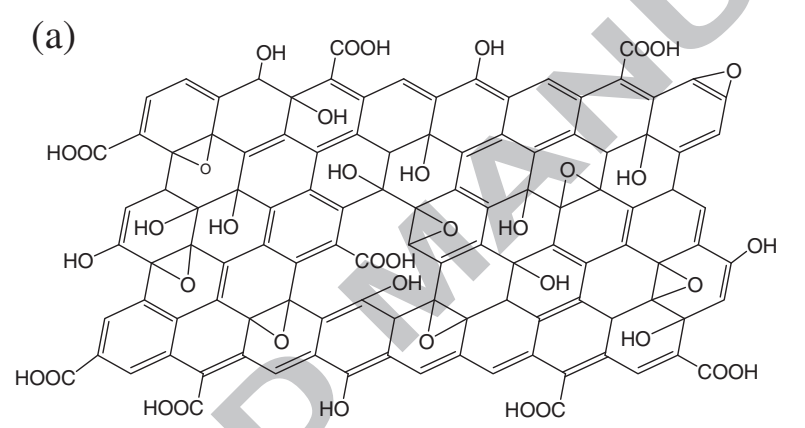

(b)

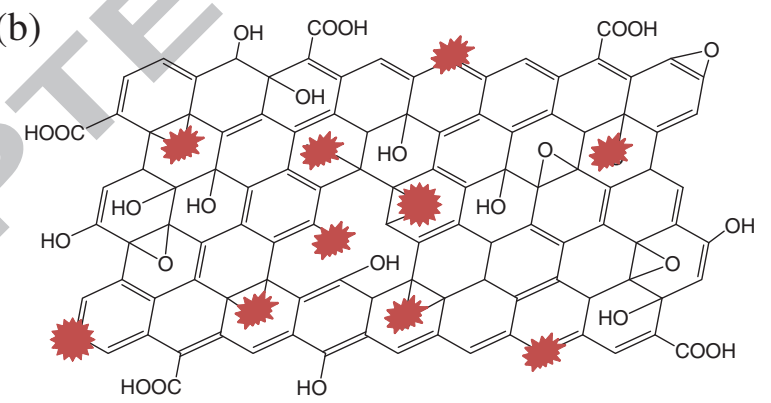

(c)

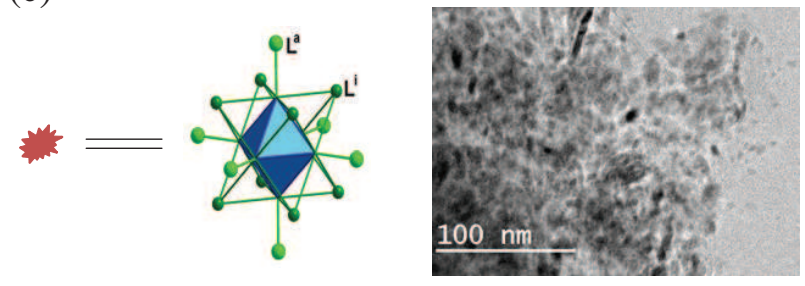

Fig. 1: A schematic illustration of (a) GO nanosheet decorated with various oxygen functionalities, (b) immobilization of $\mathrm{Cs}_{2} \mathrm{Mo}_{6} \mathrm{Br}_{8}^{\mathrm{i}} \mathrm{Br}_{6}^{\mathrm{a}}{ }_{6} /(\mathrm{TBA})_{2} \mathrm{Mo}_{6} \mathrm{Br}_{8}^{\mathrm{i}} \mathrm{Br}_{6}^{\mathrm{a}}{ }_{6}$ clusters on the $\mathrm{GO}$ nanosheets, and (c) molecular structure of $\mathrm{Mo}_{6}$ cluster 
representing position of inner and apical ligands and HRTEM image of GO loaded with ample $\mathrm{Cs}_{2} \mathrm{Mo}_{6} \mathrm{Br}_{8}^{\mathrm{i}} \mathrm{Br}_{6}^{\mathrm{a}} /$ $(\mathrm{TBA})_{2} \mathrm{Mo}_{6} \mathrm{Br}_{8}^{\mathrm{i}} \mathrm{Br}^{\mathrm{a}}{ }_{6}$ clusters.

\subsection{Experimental}

\subsection{Catalyst preparation}

\subsubsection{Preparation of $\mathrm{GO}-\mathrm{Cs}_{2} \mathrm{Mo}_{6} \mathrm{Br}_{8}^{i} \mathrm{Br}^{a}{ }_{x} / \mathrm{GO}-(\mathrm{TBA})_{2} \mathrm{Mo}_{6} \mathrm{Br}_{8}^{i} \mathrm{Br}^{a}{ }_{x}$ Composite Materials}

The GO, used as a nanostructured support material for immobilization of $\mathrm{Mo}_{6}$ clusters, was prepared in two steps using graphite powder as a precursor. Initially, graphite powder was oxidized into graphite oxide using a mixture of $\mathrm{H}_{2} \mathrm{SO}_{4}, \mathrm{NaNO}_{3}$ and $\mathrm{KMnO}_{4}$ as strong oxidants and then the oxidized product was washed with $\mathrm{H}_{2} \mathrm{O}_{2}, \mathrm{HNO}_{3}$ and ample of water in the subsequent order. In the second step, graphite oxide was exfoliated into GO using ultrasonic probe. The exfoliated product was then centrifuged at $5000 \mathrm{rpm}$ for $15 \mathrm{~min}$ to yield two distinct phases: an upper phase containing dispersible fine sheets of GO and a lower deposited semi-solid phase. The fine fraction of GO nanosheets was then used for loading of $\mathrm{Mo}_{6}$ clusters. The $\mathrm{Cs}_{2} \mathrm{Mo}_{6} \mathrm{Br}_{8}^{\mathrm{i}} \mathrm{Br}_{6}^{\mathrm{a}} /(\mathrm{TBA})_{2} \mathrm{Mo}_{6} \mathrm{Br}_{8}^{\mathrm{i}} \mathrm{Br}_{6}^{\mathrm{a}}$ cluster-based compounds were synthesized according to a previously reported procedure [42-43]. In brief, initially, $\mathrm{Mo}_{6} \mathrm{Br}_{12}$ clusterbased binary bromide was prepared by the reaction of $\mathrm{Br}_{2}$ with molybdenum powder at $750{ }^{\circ} \mathrm{C}$. Then an excision reaction was performed between a stoichiometric amount of $\mathrm{MoBr}_{2}$ and $\mathrm{CsBr}$ at $850{ }^{\circ} \mathrm{C}$ for two days. Afterwards, the prepared $\mathrm{Cs}_{2} \mathrm{Mo}_{6} \mathrm{Br}_{8}^{\mathrm{i}} \mathrm{Br}_{6}^{\mathrm{a}}{ }_{6}$ was dissolved in dry acetone, filtrated and re-crystallized in pure form. (TBA) ${ }_{2} \mathrm{Mo}_{6} \mathrm{Br}_{8}^{\mathrm{i}} \mathrm{Br}^{\mathrm{a}}{ }_{6}$ was obtained by precipitation after addition of tetrabutyl ammonium bromide in a 50:50 water: ethanol solution of $\mathrm{Cs}_{2} \mathrm{Mo}_{6} \mathrm{Br}_{8}{ }_{8} \mathrm{Br}^{\mathrm{a}}{ }_{6}$.

In order to immobilize the synthesized $\mathrm{Mo}_{6}$ clusters on $\mathrm{GO}$ nanosheets, $49 \mathrm{mg}$ of $\mathrm{Cs}_{2} \mathrm{Mo}_{6} \mathrm{Br}_{8}^{\mathrm{i}} \mathrm{Br}_{6}^{\mathrm{a}}{ }_{6}$ or $(\mathrm{TBA})_{2} \mathrm{Mo}_{6} \mathrm{Br}_{8}^{\mathrm{i}} \mathrm{Br}_{6}^{\mathrm{a}}$ clusters were separately dispersed in a mixture of water and ethanol $(100$ and $50 \mathrm{~mL}$, respectively). In the subsequent step, a $50 \mathrm{~mL}$ of $\mathrm{GO}$ aqueous dispersion $(2.24 \mathrm{mg} / \mathrm{mL})$ was gradually added into the dispersion of $\mathrm{Mo}_{6}$ clusters and the mixture was stirred for $48 \mathrm{~h}$ at room temperature. This was followed by filtration of the reaction mixture under vacuum line using membrane filter. During this process, the freely suspended $\mathrm{Cs}_{2} \mathrm{Mo}_{6} \mathrm{Br}_{8}^{\mathrm{i}} \mathrm{Br}_{6}^{\mathrm{a}} /(\mathrm{TBA})_{2} \mathrm{Mo}_{6} \mathrm{Br}_{8}^{\mathrm{i}} \mathrm{Br}_{6}^{\mathrm{a}}$ clusters passed through the membrane. The filtrate cake, composed of immobilized $\mathrm{Mo}_{6}$ clusters on $\mathrm{GO}$ nanosheets was washed five 
times with ethanol to afford the final product, GO-Cs ${ }_{2} \mathrm{Mo}_{6} \mathrm{Br}_{8}^{\mathrm{i}} \mathrm{Br}^{\mathrm{a}}{ }_{\mathrm{x}}$ or GO-(TBA) ${ }_{2} \mathrm{Mo}_{6} \mathrm{Br}_{8}^{\mathrm{i}} \mathrm{Br}^{\mathrm{a}}{ }_{\mathrm{x}}$. Finally, the product was dried in an oven for chemical and structural characterizations and then used for photocatalytic reduction of $\mathrm{CO}_{2}$. Figure 1 shows the schematic illustrations of $\mathrm{GO}, \mathrm{Mo}_{6}$ clusters and immobilized clusters on the GO nanosheets.

2.2 Chemical and Structural Characterizations of $\mathrm{GO}_{-} \mathrm{Cs}_{2} \mathrm{Mo}_{6} \mathrm{Br}_{8}^{i} \mathrm{Br}^{a}{ }_{x} / \mathrm{GO}-(\mathrm{TBA})_{2} \mathrm{Mo}_{6} \mathrm{Br}_{8}^{i} \mathrm{Br}^{a}{ }_{x}$ Composite Materials

Fourier transform infrared (FTIR) spectra of $\mathrm{GO}, \mathrm{Mo}_{6}$ clusters and their composites were recorded on a Thermo-Nicolet 8700 Research spectrophotometer (Thermo Scientific) with a resolution of $4 \mathrm{~cm}^{-1}$. X-ray photoelectron spectroscopy (XPS, JPS-9010TRX, JEOL Ltd.) measurements were carried out using thin films of GO, GO-Cs ${ }_{2} \mathrm{Mo}_{6} \mathrm{Br}_{8}^{\mathrm{i}} \mathrm{Br}^{\mathrm{a}}{ }_{\mathrm{x}}$ and GO-(TBA $)_{2} \mathrm{Mo}_{6} \mathrm{Br}_{8}^{\mathrm{i}}{ }_{8} \mathrm{Br}^{\mathrm{a}}{ }_{\mathrm{x}}$ samples. The XPS measurements were executed using a $\mathrm{MgK} \alpha$ line as the $\mathrm{X}$-ray source. The peak-fitting of the $\mathrm{C} 1 \mathrm{~s}$ spectra was performed by using a Gaussian-Lorentzian function after performing a Shirley background correction. Thermogravimetric analyses (TGA) were recorded on a thermal analyzer (Diamond, PerkinElmer). All samples were analyzed in the temperature range of $35-550{ }^{\circ} \mathrm{C}$ under a steady flow of nitrogen. The high resolution microscopic features of GO, GO-Cs ${ }_{2} \mathrm{Mo}_{6} \mathrm{Br}_{8}^{\mathrm{i}} \mathrm{Br}^{\mathrm{a}}{ }_{\mathrm{x}}$ and GO-(TBA) $)_{2} \mathrm{Mo}_{6} \mathrm{Br}_{8}^{\mathrm{i}} \mathrm{Br}^{\mathrm{a}}{ }_{\mathrm{x}}$ samples were examined on high resolution transmission electron microscope (HRTEM) by drop casting their ethanol solutions on the TEM grids. Field emission scanning electron microscopy (FESEM) analyses were carried out using an FEI Quanta $200 \mathrm{~F}$. The elemental distribution in the developed composite materials was recorded by using energy dispersive spectrometer (EDS) coupled with FESEM. UV/Vis spectra were measured on a Hitachi U-2900 UV/Vis spectrometer with a path length of $1 \mathrm{~cm}$ using quartz cuvettes.

\subsection{Photocatalytic Reduction of $\mathrm{CO}_{2}$}

Photocatalytic reduction of $\mathrm{CO}_{2}$ was carried out using $\mathrm{GO}-\mathrm{Cs}_{2} \mathrm{Mo}_{6} \mathrm{Br}_{8}^{\mathrm{i}} \mathrm{Br}^{\mathrm{a}}{ }_{\mathrm{x}}$ and GO- $(\mathrm{TBA})_{2} \mathrm{Mo}_{6} \mathrm{Br}_{8}^{\mathrm{i}} \mathrm{Br}^{\mathrm{a}}{ }_{\mathrm{x}}$ composites as the photocatalysts. The experiments were performed in borosil cylindrical vessel $(100 \mathrm{~mL})$ of 5 $\mathrm{cm}$ diameter. Photo-irradiation was carried out under visible light by using $20 \mathrm{~W}$ white cold LED flood light (model no. HP-FL-20W-F-Hope LED Opto-Electric Co., Ltd.). The intensity of the light at vessel was measured by intensity meter and was found to be $75 \mathrm{Wm}^{-2}$. The vessel was charged initially with water (10 $\mathrm{mL}$ ) and DMF (40 mL), and then the solution was degassed by continuous purging of nitrogen for $15 \mathrm{~min}$. 
Subsequently, $\mathrm{CO}_{2}$ was bubbled through the solution for at least $30 \mathrm{~min}$ to saturate the solution, then GO$\mathrm{Cs}_{2} \mathrm{Mo}_{6} \mathrm{Br}_{8}^{\mathrm{i}} \mathrm{Br}^{\mathrm{a}}{ }_{\mathrm{x}}$ or GO-(TBA)$)_{2} \mathrm{Mo}_{6} \mathrm{Br}_{8}^{\mathrm{i}} \mathrm{Br}^{\mathrm{a}}{ }_{x}$ catalyst $(100 \mathrm{mg})$ was added to the above-described solution. The vessel was tightly closed during the photocatalytic reaction and stirred continuously by a magnetic stirring bar to prevent sedimentation of the catalyst. Samples were collected every $2 \mathrm{~h}$ by using a needle, and the catalyst was removed by filtration $(0.2 \mu \mathrm{m}$ PTFE, $13 \mathrm{~mm}$ diameter). Quantitative determination of reaction product was achieved by using GC-FID (Varian CP3800 by using CP Sil 24CB LOW BLEED/MS column, flow rate: $0.5 \mathrm{~mL} \cdot \mathrm{min}^{-1}$, injector temperature: $250{ }^{\circ} \mathrm{C}$, FID detector temperature: $275{ }^{\circ} \mathrm{C}$ ). A calibration curve was generated for quantification and for confirmation of linear response of the GC-FID system. Further confirmation of methanol production was done by HPLC (Shimadzu UFLC, by using Oyster BDS Premium C18 250X4.6mm, $5 \mu \mathrm{m}$ column, mobile phase acetonitrile: acetone (65:35), flow rate: $0.5 \mathrm{~mL} / \mathrm{min}$ at $205 \mathrm{~nm}$ ). Blank reactions were conducted to ensure that methanol production was due to the photo-reduction of $\mathrm{CO}_{2}$ and to eliminate surrounding interference. For the determination of gaseous products, $20 \mu \mathrm{L}$ sample was withdrawn and analyzed with the help of GC-TCD and GC-FID (Agilent 7890A GC system) equipped with RGA (refinery gas analyzer) capillary column; flow rate $\left(\mathrm{H}_{2}: 35 \mathrm{~mL} / \mathrm{min}\right.$, air: $350 \mathrm{~mL} / \mathrm{min}$, makeup flow: 27 $\mathrm{mL} / \mathrm{min}$, for TCD reference flow: $45 \mathrm{~mL} / \mathrm{min}$, Helium flow: $2 \mathrm{~mL} / \mathrm{min}$ ), injector temperature: $220^{\circ} \mathrm{C}$, TCD detector temperature and FID detector temperature: $220^{\circ} \mathrm{C}$.

\subsection{Results and discussion}

\subsection{Synthesis and characterization of catalyst}

The chemical and structural features of $\mathrm{GO}$ and its composites i.e. GO-Cs $\mathrm{Mo}_{6} \mathrm{Br}_{8}^{\mathrm{i}} \mathrm{Br}^{\mathrm{a}}{ }_{\mathrm{x}}$ and GO(TBA) ${ }_{2} \mathrm{MO}_{6} \mathrm{Br}_{8}^{\mathrm{i}} \mathrm{Br}_{\mathrm{x}}^{\mathrm{a}}$ were thoroughly characterized by FTIR, XPS, TG-DTA, HRTEM, EDX and UV-Vis analyses. The FTIR spectrum of GO (Figure 2) exhibited strong characteristics vibrational bands at 3419, $1732,1622,1373,1263$ and $1064 \mathrm{~cm}^{-1}$, which are attributed to $\mathrm{O}-\mathrm{H}$ stretch, $\mathrm{C}=\mathrm{O}$ stretch, $\mathrm{H}_{2} \mathrm{O}$ bending modes and $\mathrm{C}=\mathrm{C}$ stretch, $\mathrm{O}-\mathrm{H}$ bending and $\mathrm{C}-\mathrm{O}$ stretch, respectively. The strong intensities of these vibrations revealed the presence of ample hydroxyl, epoxy, carboxylic, carbonyl, phenolic, etc. functional groups in the GO scaffold. The $\mathrm{Cs}_{2} \mathrm{Mo}_{6} \mathrm{Br}_{8}^{\mathrm{i}} \mathrm{Br}^{\mathrm{a}}{ }_{\mathrm{x}}$ has no vibrational signature, except a strong band at $1620 \mathrm{~cm}^{-1}$, attributed to the bending mode of adsorbed water molecules in the cluster compound (Figure 2a). 
In contrast, $(\mathrm{TBA})_{2} \mathrm{Mo}_{6} \mathrm{Br}_{8}^{\mathrm{i}} \mathrm{Br}_{6}^{\mathrm{a}}$ showed strong characteristic vibrational modes in the range of $3000-2800 \mathrm{~cm}^{-}$ 1, attributed to the $\mathrm{C}-\mathrm{H}$ stretches of methylene and methyl groups (Figure 2b). Furthermore, strong vibrations at 1466 and $1383 \mathrm{~cm}^{-1}$ associated with $\mathrm{C}-\mathrm{H}$ bending modes revealed the presence of butyl chains in the (TBA) $)_{2} \mathrm{Mo}_{6} \mathrm{Br}_{8}^{\mathrm{i}} \mathrm{Br}_{6}^{\mathrm{a}}$ clusters. The appearance of $\mathrm{C}-\mathrm{H}$ vibrations in the GO- $(\mathrm{TBA})_{2} \mathrm{Mo}_{6} \mathrm{Br}_{8}^{\mathrm{i}} \mathrm{Br}_{\mathrm{x}}{ }^{\mathrm{a}}$ composite (inset of Figure 2b) suggested the loading of (TBA) ${ }_{2} \mathrm{Mo}_{6} \mathrm{Br}_{8}^{\mathrm{i}} \mathrm{Br}_{6}^{\mathrm{a}}$ on the GO nanosheets. Both GO-Cs $\mathrm{Mo}_{6} \mathrm{Br}_{8}^{\mathrm{i}} \mathrm{Br}^{\mathrm{a}}{ }_{\mathrm{x}}$ and GO-(TBA $)_{2} \mathrm{Mo}_{6} \mathrm{Br}_{8}^{\mathrm{i}} \mathrm{Br}^{\mathrm{a}}{ }_{\mathrm{x}}$ composites exhibited the characteristic vibrations of oxygen functionalities of GO, indicating that most of oxygen functionalities were remained intact and presented in both $G O-\mathrm{Cs}_{2} \mathrm{Mo}_{6} \mathrm{Br}_{8}^{\mathrm{i}} \mathrm{Br}^{\mathrm{a}}{ }_{\mathrm{x}}$ and GO-(TBA) $)_{2} \mathrm{Mo}_{6} \mathrm{Br}_{8}^{\mathrm{i}} \mathrm{Br}_{\mathrm{x}}^{\mathrm{a}}$ composites. In order to probe the chemical states and plausible interaction between the $\mathrm{Mo}_{6}$ clusters and GO, all samples were thoroughly characterized by XPS. 


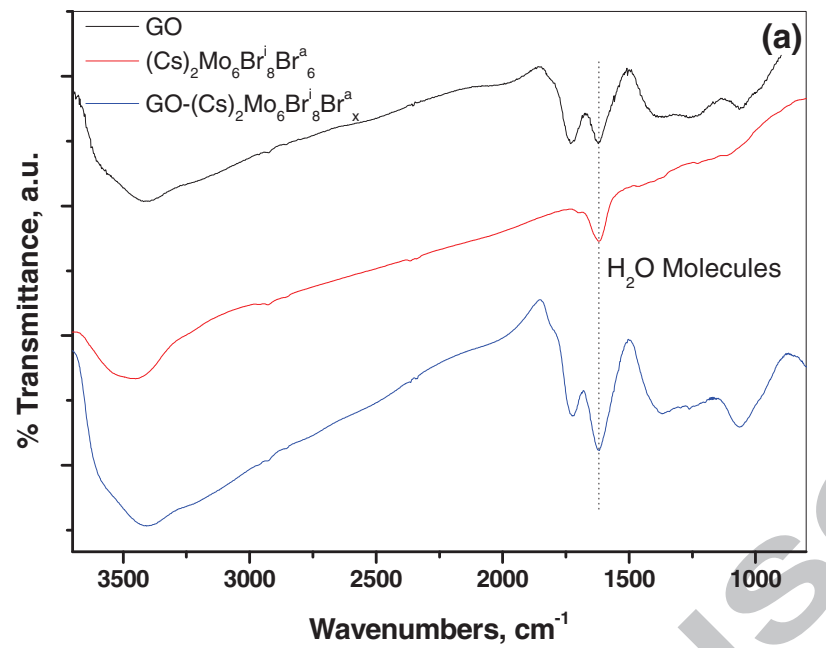

\section{(a)}

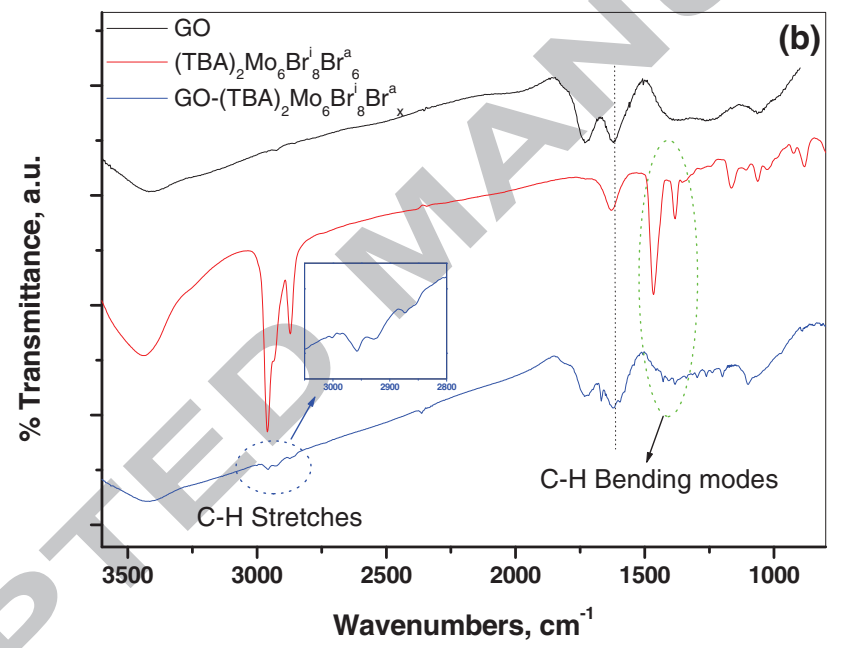

Fig. 2: FTIR spectra of (a) GO, $\mathrm{Cs}_{2} \mathrm{Mo}_{6} \mathrm{Br}_{8}^{\mathrm{i}} \mathrm{Br}^{\mathrm{a}}{ }_{x}$ clusters and $\mathrm{GO}-\mathrm{Cs}_{2} \mathrm{Mo}_{6} \mathrm{Br}_{8}^{\mathrm{i}} \mathrm{Br}^{\mathrm{a}}{ }_{x}$ composite, and (b) GO, (TBA) ${ }_{2} \mathrm{Mo}_{6} \mathrm{Br}_{8}^{\mathrm{i}} \mathrm{Br}_{6}^{\mathrm{a}}$ clusters and GO-(TBA) ${ }_{2} \mathrm{Mo}_{6} \mathrm{Br}_{8}^{\mathrm{i}} \mathrm{Br}_{6}^{\mathrm{a}}{ }_{6}$ composite. The presence of $\mathrm{C}-\mathrm{H}$ vibrational modes in GO(TBA $)_{2} \mathrm{Mo}_{6} \mathrm{Br}_{8}^{\mathrm{i}} \mathrm{Br}_{6}^{\mathrm{a}}{ }_{6}$ composite reveals the loading of $(\mathrm{TBA})_{2} \mathrm{Mo}_{6} \mathrm{Br}_{8}^{\mathrm{i}} \mathrm{Br}_{6}^{\mathrm{a}}{ }_{6}$ clusters on the $\mathrm{GO}$ nanosheets. 

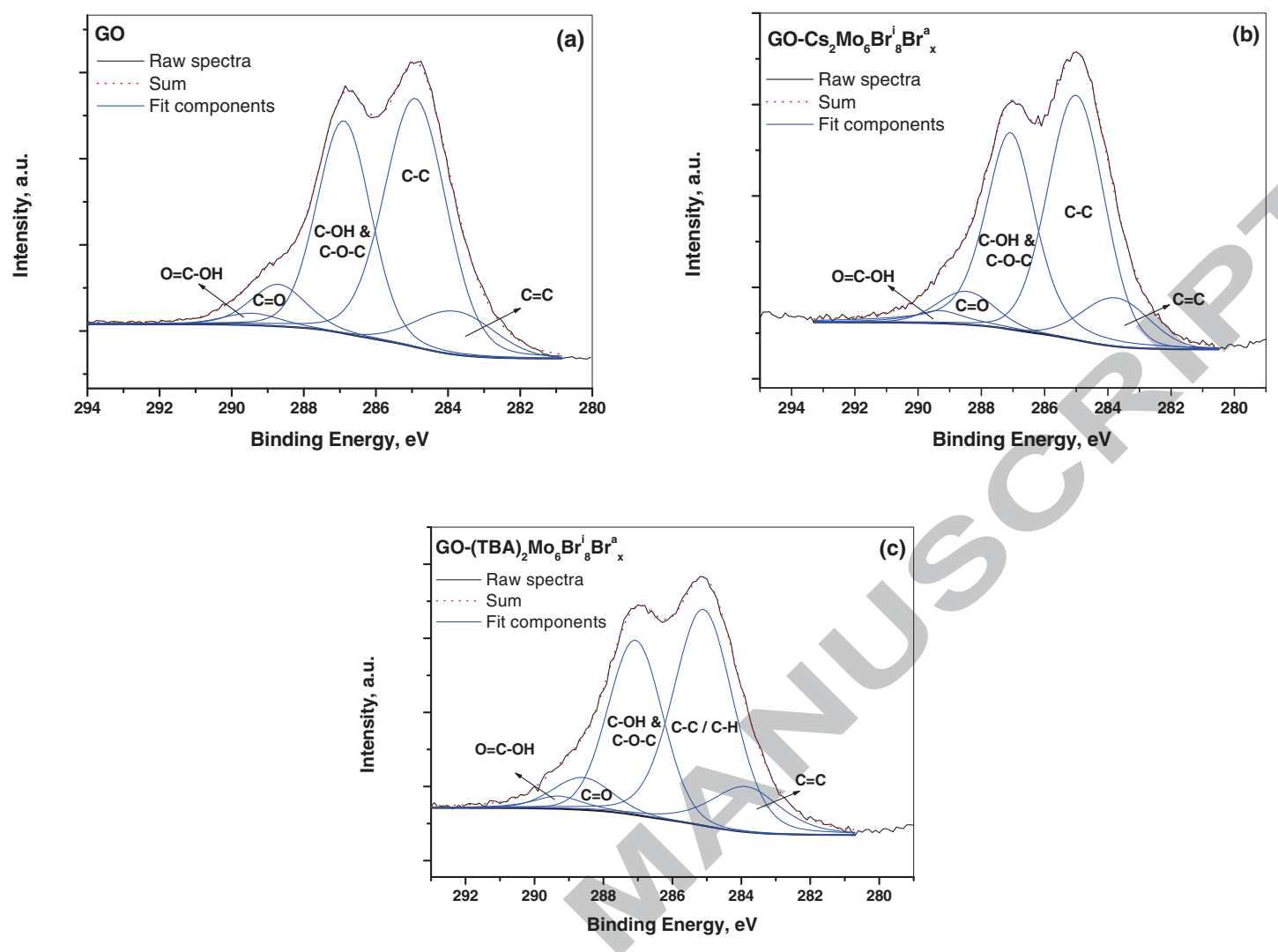

Fig 3: High resolution C1s XPS spectra of (a) GO, (b) GO-Cs ${ }_{2} \mathrm{Mo}_{6} \mathrm{Br}_{8}^{\mathrm{i}} \mathrm{Br}^{\mathrm{a}}{ }_{\mathrm{x}}$ and (c) GO-(TBA) ${ }_{2} \mathrm{Mo}_{6} \mathrm{Br}_{8}^{\mathrm{i}} \mathrm{Br}_{6}^{\mathrm{a}}$ samples. The deconvoluted components illustrate the various types of oxygen functionalities in the materials.
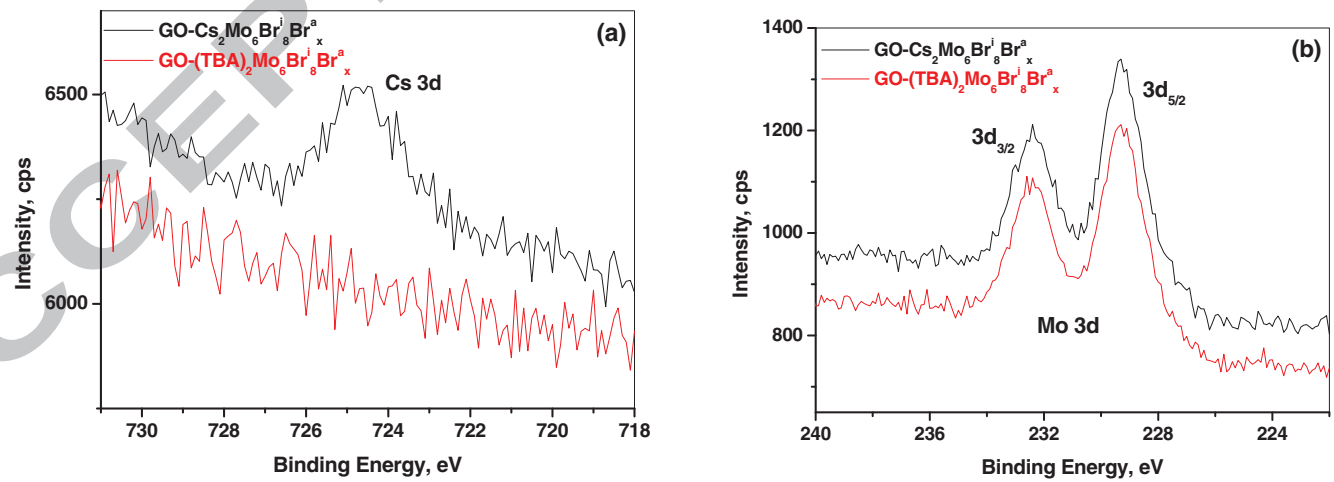

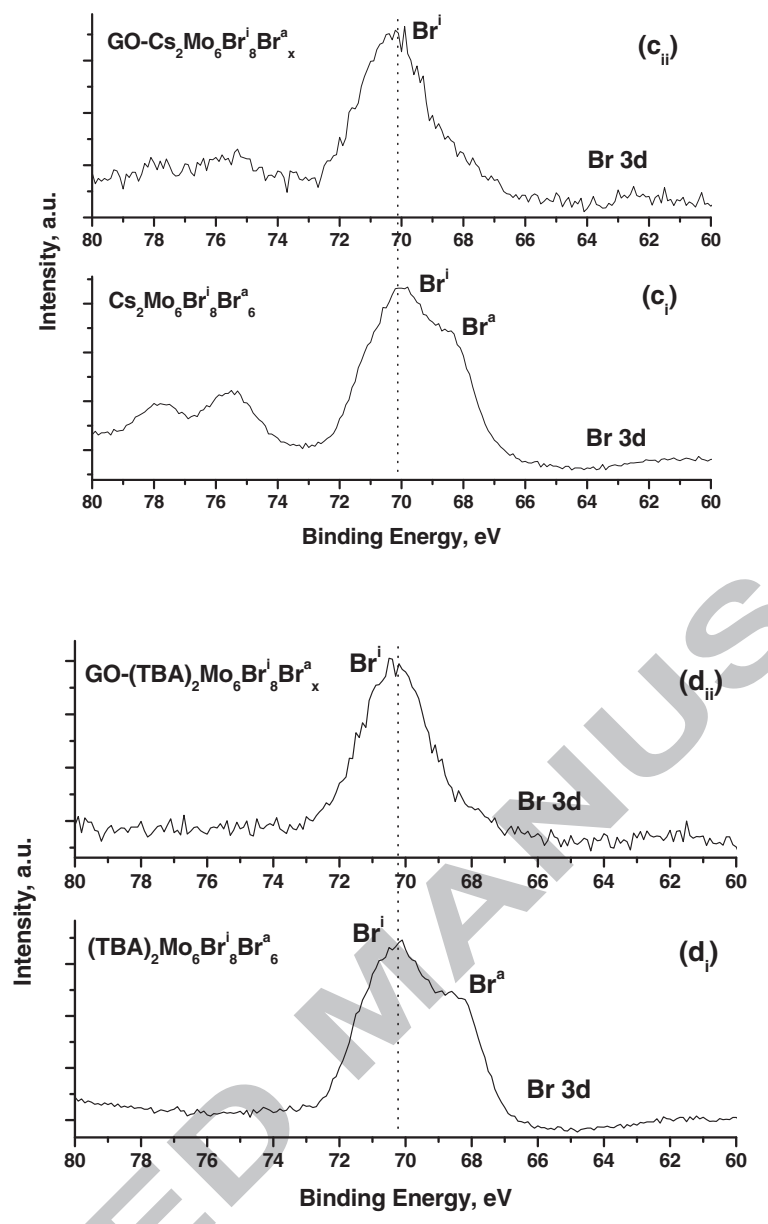

Fig 4: XPS spectra of (a) Cs 3d; (b) Mo 3d; (c) Br 3d regions for $\mathrm{Cs}_{2} \mathrm{Mo}_{6} \mathrm{Br}^{\mathrm{i}}{ }_{8} \mathrm{Br}^{\mathrm{a}}{ }_{\mathrm{x}}$ and $\mathrm{GO}-\mathrm{Cs}_{2} \mathrm{Mo}_{6} \mathrm{Br}_{8}^{\mathrm{i}} \mathrm{Br}^{\mathrm{a}}{ }_{\mathrm{x}}$; (d) $\mathrm{Br}^{3 \mathrm{~d}}$ regions for $(\mathrm{TBA})_{2} \mathrm{Mo}_{6} \mathrm{Br}_{8}^{\mathrm{i}} \mathrm{Br}_{\mathrm{x}}^{\mathrm{a}}$ and GO-(TBA) ${ }_{2} \mathrm{Mo}_{6} \mathrm{Br}_{8}^{\mathrm{i}} \mathrm{Br}_{\mathrm{x}}^{\mathrm{a}}$ composites.

XPS analyses of GO, GO-Cs ${ }_{2} \mathrm{Mo}_{6} \mathrm{Br}_{8}{ }_{8} \mathrm{Br}^{\mathrm{a}}{ }_{\mathrm{x}}$ and $\mathrm{GO}-(\mathrm{TBA})_{2} \mathrm{Mo}_{6} \mathrm{Br}_{8}^{\mathrm{i}} \mathrm{Br}^{\mathrm{a}}{ }_{\mathrm{x}}$ samples were carried out to elucidate the quantitative estimation along with chemical changes in the $\mathrm{GO}$ and $\mathrm{Mo}_{6}$ clusters (Figures 3 and 4). The high-resolution C 1s spectrum of GO exhibited an overlapped double peak structure with small tail at higher binding energy attributed to different types of oxygen containing functional groups in the GO scaffold. The peak-fitting of C 1s spectrum of GO can be deconvoluted into five chemically-shifted components (Figure 3a). The $\mathrm{C} 1 \mathrm{~s}$ peak centered at $284.9 \mathrm{eV}$ as a major component of $\mathrm{GO}$ scaffold is attributed to $\mathrm{C}-\mathrm{C} / \mathrm{C}-\mathrm{H}$ carbons. The peak at relatively lower binding energy $(284.0 \mathrm{eV})$ is due to $\mathrm{C}=\mathrm{C}$ carbon and suggests the presence of 
unoxidized domains of $\mathrm{sp}^{2}$ carbon. Three additional overlapped components at $286.8,288.6$ and $289.5 \mathrm{eV}$ are assigned to the hydroxyl/epoxide $(\mathrm{C}-\mathrm{OH} / \mathrm{C}-\mathrm{O}-\mathrm{C})$, carbonyl $(\mathrm{C}=\mathrm{O})$ and carboxyl $(\mathrm{COOH})$ functional groups, respectively [44-45]. Figure 3 indicates that all characteristic peaks of $\mathrm{C} 1 \mathrm{~s}$ spectra remained intact, when $\mathrm{Mo}_{6}$ clusters were immobilized on the GO nanosheets and no significant changes were observed. Furthermore, the loading of $\mathrm{Mo}_{6}$ clusters onto GO nanosheets was deduced by appearance of additional peaks at 724.5, 229.3 and $70.2 \mathrm{eV}$ attributed to $\mathrm{Cs} 3 \mathrm{~d}$, Mo $3 \mathrm{~d}$ and $\mathrm{Br} 3 \mathrm{~d}$, respectively (Figure 4). The Mo $3 \mathrm{~d}$ peaks at 229.3 and 232.4 $\mathrm{eV}$ are due to the split components of $3 \mathrm{~d}_{5 / 2}$ and $3 \mathrm{~d}_{3 / 2}$, respectively and revealed the Mo(II) oxidation state $[24,46]$. The positions of $\mathrm{Mo} 3 \mathrm{~d}_{5 / 2}$ and $3 \mathrm{~d}_{3 / 2}$ components in the GO- $\mathrm{Cs}_{2} \mathrm{Mo}_{6} \mathrm{Br}_{8}^{\mathrm{i}} \mathrm{Br}^{\mathrm{a}}{ }_{\mathrm{x}}$ and GO(TBA) ${ }_{2} \mathrm{Mo}_{6} \mathrm{Br}_{8}^{\mathrm{i}} \mathrm{Br}^{\mathrm{a}}{ }_{\mathrm{x}}$ are comparable to those obtained for their pure $\mathrm{Mo}_{6}$ clusters. These results suggest that the cluster core $\mathrm{Mo}_{6} \mathrm{Br}_{8}^{\mathrm{i}}$ remained intact during cluster immobilization on the $\mathrm{GO}$ nanosheets. The $\mathrm{Cs} 3 \mathrm{~d}$ peaks at 724.5 and $739 \mathrm{eV}$ are attributed to the split components of $3 \mathrm{~d}_{5 / 2}$ and $3 \mathrm{~d}_{3 / 2}$, respectively and indicate the presence of $\mathrm{Cs}(\mathrm{I})$ in the $\mathrm{GO}-\mathrm{Cs}_{2} \mathrm{Mo}_{6} \mathrm{Br}_{8}^{\mathrm{i}} \mathrm{Br}^{\mathrm{a}}{ }_{\mathrm{x}}$ composite (Figure 4a). The Cs $3 \mathrm{~d}_{3 / 2}$ peak couldn't appear explicitly, as it was diminished by nearby strong peak of $\mathrm{O}(\mathrm{KVV})$ as shown in Figure $\mathrm{S} 1$ (Electronic supporting information).

The internal core of the octahedral $\mathrm{Mo}_{6}$ clusters consists of eight $\mathrm{Mo}-\mathrm{Br}^{\mathrm{i}}$ bonds and the remaining six $\mathrm{Br}^{-}$are placed on apical position through $\mathrm{Mo}-\mathrm{Br}^{\mathrm{a}}$ bonds having strong ionic character. These apical $\mathrm{Br}^{-}$functionalities are prone to interact with other chemical functionalities and facilitate their immobilization onto solid supports. The XPS spectra of $\mathrm{Mo}_{6}$ cluster compounds and their immobilized composites GO-Cs $2 \mathrm{Mo}_{6} \mathrm{Br}_{8}^{\mathrm{i}} \mathrm{Br}^{\mathrm{a}}{ }_{x}$ and GO(TBA) ${ }_{2} \mathrm{Mo}_{6} \mathrm{Br}_{8}^{\mathrm{i}} \mathrm{Br}^{\mathrm{a}}$ are shown in Figure $4 \mathrm{c}-\mathrm{d}$. The $\mathrm{Br} 3 \mathrm{~d}$ peak in $\mathrm{Mo}_{6}$ clusters is composed of two components at 70.2 and $68.6 \mathrm{eV}$, which are attributed to covalently bonded inner $\mathrm{Br}$ atoms $\left(\mathrm{Br}^{\mathrm{i}}\right)$ and apical bromide ions $\left(\mathrm{Br}^{\mathrm{a}}\right)$ of $\mathrm{Mo}_{6}$ clusters, respectively [47-48]. The $\mathrm{Br} 3 \mathrm{~d}$ spectra of $\mathrm{GO}_{-} \mathrm{Cs}_{2} \mathrm{Mo}_{6} \mathrm{Br}^{\mathrm{i}}{ }_{8} \mathrm{Br}^{\mathrm{a}}{ }_{\mathrm{x}}$ and GO(TBA) ${ }_{2} \mathrm{Mo}_{6} \mathrm{Br}_{8}{ }_{8}^{\mathrm{i}} \mathrm{Br}^{\mathrm{a}}{ }_{\mathrm{x}}$ composites (Figure $4 \mathrm{c}-\mathrm{d}$ ) showed that the peak component at $68.6 \mathrm{eV}$, attributed to $\mathrm{Br}^{\mathrm{a}}$ ligands, is almost diminished, demonstrating the elimination of $\mathrm{Br}^{\mathrm{a}}$ ligands. This suggests the reaction of $\mathrm{Br}^{\mathrm{a}}$ of $\mathrm{Mo}_{6}$ clusters with hydroxyl / oxygen carrying functional groups of GO nanosheets. As a result, $\mathrm{Mo}_{6}$ clusters immobilized on the GO nanosheets by covalent linkage and $\mathrm{Br}^{\mathrm{a}}$ are eliminated during immobilization process. The atomic $\%$ of Mo and $\mathrm{Br}$ components in both $(\mathrm{TBA})_{2} \mathrm{Mo}_{6} \mathrm{Br}_{8}^{\mathrm{i}} \mathrm{Br}_{6}^{\mathrm{a}}$ cluster and GO-(TBA) ${ }_{2} \mathrm{Mo}_{6} \mathrm{Br}_{8}^{\mathrm{i}} \mathrm{Br}^{\mathrm{a}} \mathrm{X}$ composites were calculated based on XPS study, to determine the interaction between the (TBA) ${ }_{2} \mathrm{Mo}_{6} \mathrm{Br}_{8}^{\mathrm{i}} \mathrm{Br}_{6}^{\mathrm{a}}$ 
cluster and GO nanosheets. The experimental ratio of $\mathrm{Br} / \mathrm{Mo}=2.6$ in $(\mathrm{TBA})_{2} \mathrm{Mo}_{6} \mathrm{Br}_{8}^{\mathrm{i}} \mathrm{Br}_{6}^{\mathrm{a}}$ cluster agrees with the theoretical value (2.33). After immobilization of (TBA) $)_{2} \mathrm{Mo}_{6} \mathrm{Br}_{8}^{\mathrm{i}} \mathrm{Br}^{\mathrm{a}}{ }_{6}$ cluster, the ratio of $\mathrm{Br} / \mathrm{Mo}$ decreased to 1.6, which is closer to the expected value (1.33) for a $\mathrm{Br}^{\mathrm{i}} / \mathrm{Mo}$ cluster core. Recently, Sutherland et al. have further demonstrated that labile terminal nitro groups at apical position in $\mathrm{Mo}_{6}$ clusters were eliminated during their chemical attachment to solid supports [49].

UV/Vis absorption spectra of $\mathrm{Cs}_{2} \mathrm{Mo}_{6} \mathrm{Br}_{8}^{\mathrm{i}} \mathrm{Br}_{6}^{\mathrm{a}}{ }_{6}$ and $(\mathrm{TBA})_{2} \mathrm{Mo}_{6} \mathrm{Br}_{8}^{\mathrm{i}} \mathrm{Br}^{\mathrm{a}}{ }_{6}$ in acetonitrile exhibited sharp peaks at 242 and $243 \mathrm{~nm}$ due to the inter ligand transition and small humps at $386 \mathrm{~nm}$ and $380 \mathrm{~nm}$ due to the metal-to-ligand charge-transfer (MLCT) transitions, respectively (Figure S2a,b). For GO, a characteristic absorption band at $227 \mathrm{~nm}$ due to $\pi \rightarrow \pi^{*}$ transition of discrete units of $\mathrm{sp}^{2}$ carbon conjugated network and a small hump at $300 \mathrm{~nm}$ due to $\mathrm{n} \rightarrow \pi^{*}$ of carbonyl groups were observed. Immobilization of $\mathrm{Mo}_{6}$ clusters to GO enhanced the overall absorption pattern as shown in Figure S2.

In order to confirm the visible light absorption, we calculated the band gap of $\mathrm{GO}, \mathrm{Cs}_{2} \mathrm{Mo}_{6} \mathrm{Br}_{8}^{\mathrm{i}} \mathrm{Br}_{6}^{\mathrm{a}}{ }_{6}$ cluster, GO$\mathrm{Cs}_{2} \mathrm{Mo}_{6} \mathrm{Br}_{8}^{\mathrm{i}} \mathrm{Br}^{\mathrm{a}}{ }_{\mathrm{x}}$ composite, $(\mathrm{TBA})_{2} \mathrm{Mo}_{6} \mathrm{Br}_{8}^{\mathrm{i}} \mathrm{Br}_{6}{ }_{6}^{\mathrm{a}}$ cluster and GO-(TBA) $)_{2} \mathrm{Mo}_{6} \mathrm{Br}_{8}^{\mathrm{i}} \mathrm{Br}^{\mathrm{a}}{ }_{\mathrm{x}}$ composite with the help of Tauc plot as shown in Figure S3. The band gap value for GO was found to be $2.90 \mathrm{eV}$ was in well agreement with the reported literature [50]. For $\mathrm{Cs}_{2} \mathrm{Mo}_{6} \mathrm{Br}_{8}^{\mathrm{i}} \mathrm{Br}_{6}^{\mathrm{a}}{ }_{6}$ and (TBA) $)_{2} \mathrm{Mo}_{6} \mathrm{Br}_{8}^{\mathrm{i}} \mathrm{Br}^{\mathrm{a}}{ }_{6}$ clusters compounds, two band gap values were obtained; the $4.07 \mathrm{eV}$ and $4.16 \mathrm{eV}$ were due to the interligand transitions while the $2.40 \mathrm{eV}$ and $2.47 \mathrm{eV}$ were ascribed to the MLCT transitions, respectively. After immobilization of $\mathrm{Mo}_{6}$ clusters on GO, the band gap values significantly decreased to 0.9 and $1.5 \mathrm{eV}$ for $\mathrm{GO}-\mathrm{Cs}_{2} \mathrm{Mo}_{6} \mathrm{Br}_{8}^{\mathrm{i}} \mathrm{Br}_{\mathrm{x}}^{\mathrm{a}}$ and GO$(\mathrm{TBA})_{2} \mathrm{Mo}_{6} \mathrm{Br}_{8}^{\mathrm{i}} \mathrm{Br}^{\mathrm{a}} \times$ composite, respectively.

The thermal behaviour of $\mathrm{GO}, \mathrm{Mo}_{6}$ clusters and their composites were examined by thermogravimetric analysis (TGA). GO showed two characteristic major weight losses in the range of $50-110{ }^{\circ} \mathrm{C}$ and $170-240{ }^{\circ} \mathrm{C}$, owing to evaporation of trapped water molecules and thermal decomposition of labile oxygen functionalities in GO scaffold, respectively (Figure 5). The $\mathrm{Cs}_{2} \mathrm{Mo}_{6} \mathrm{Br}_{8}^{\mathrm{i}} \mathrm{Br}^{\mathrm{a}}{ }_{6}$ cluster is found to be thermally stable upto $500{ }^{\circ} \mathrm{C}$, whereas $(\mathrm{TBA})_{2} \mathrm{Mo}_{6} \mathrm{Br}_{8}^{\mathrm{i}} \mathrm{Br}_{6}^{\mathrm{a}}{ }_{6}$ cluster has significant mass loss about $27 \%$ in the range of $320-390{ }^{\circ} \mathrm{C}$ with maximum loss at $368{ }^{\circ} \mathrm{C}$, most likely due to the thermal decomposition of TBA units (Figure $\mathrm{b}_{\mathrm{ii}}$ ). However, GO-(TBA) ${ }_{2} \mathrm{Mo}_{6} \mathrm{Br}_{8}{ }_{8}^{\mathrm{i}} \mathrm{Br}^{\mathrm{a}}{ }_{\mathrm{x}}$ composite showed $4.5 \%$ weight loss (due to TBA units and oxygen functionalities of GO) in the range of $295-375{ }^{\circ} \mathrm{C}$ with maximum loss at $340^{\circ} \mathrm{C}$ (Figure $b_{\text {iii }}$. Plausibly, the presence of residual 
oxygen functionalities in the GO-(TBA $)_{2} \mathrm{Mo}_{6} \mathrm{Br}_{8}^{\mathrm{i}} \mathrm{Br}^{\mathrm{a}}{ }_{\mathrm{x}}$ composite has facilitated the decomposition of TBA units in supported composite comparatively at lower temperature. Based on the TGA results, the calculated weight loss due to the supported TBA cluster units was found to be $1.6 \%$.
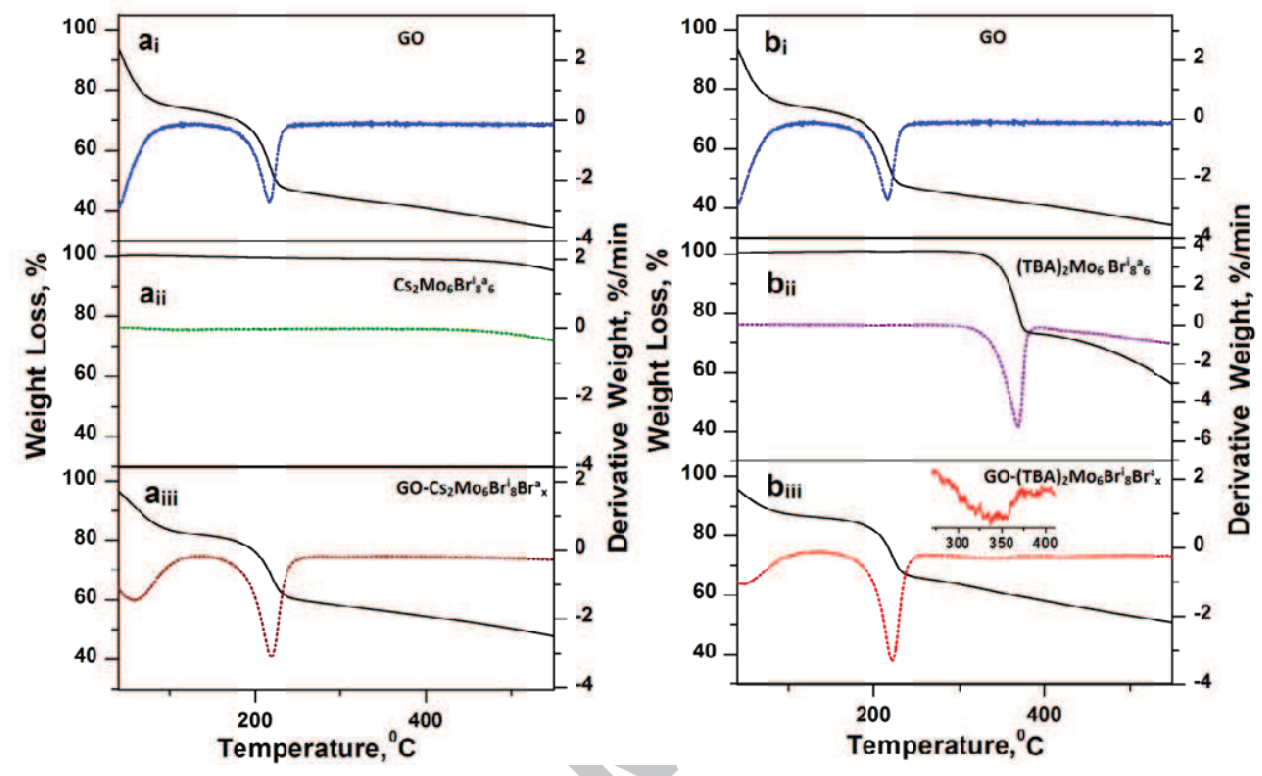

Fig 5: TG-DTA patterns of (a) $\mathrm{GO}, \mathrm{Cs}_{2} \mathrm{Mo}_{6} \mathrm{Br}_{8}^{\mathrm{i}} \mathrm{Br}^{\mathrm{a}}{ }_{6}$ cluster and $\mathrm{GO}-\mathrm{Cs}_{2} \mathrm{Mo}_{6} \mathrm{Br}_{8}^{\mathrm{i}} \mathrm{Br}^{\mathrm{a}}{ }_{x}$ composite; (b) GO, $(\mathrm{TBA})_{2} \mathrm{Mo}_{6} \mathrm{Br}_{8}^{\mathrm{i}} \mathrm{Br}_{6}^{\mathrm{a}}{ }_{6}$ cluster and GO-(TBA) $)_{2} \mathrm{Mo}_{6} \mathrm{Br}_{8}^{\mathrm{i}} \mathrm{Br}^{\mathrm{a}}{ }_{x}$ composite over the temperature range of $30-550{ }^{\circ} \mathrm{C}$ under nitrogen flow.

The nano-structural features of GO and its composites with $\mathrm{Mo}_{6}$ clusters were examined by HRTEM. Figure 6a shows plenty of wrinkle and folded regions in the HRTEM image of GO scaffolds. These features are attributed to the $\mathrm{sp}^{3}$ carbons, which are linked to oxygen functionalities in the basal plane and various structural defects. Significant structural changes are observed when $\mathrm{Mo}_{6}$ clusters were immobilized on GO nanosheets (Figure $6 \mathrm{~b}-\mathrm{c}$ ). The $\mathrm{Mo}_{6}$ clusters are uniformly distributed over the GO surface and they are seen as dark grey features in the range of 2-10 nm. The hydrodynamic diameter of $\mathrm{Cs}_{2} \mathrm{Mo}_{6} \mathrm{Br}_{8}^{\mathrm{i}} \mathrm{Br}^{\mathrm{a}}{ }_{6}$ clusters is reported to be $2.5 \mathrm{~nm}$ by dynamic light scattering (DLS) method, whereas the crystallographic cluster unit size of these clusters is $1.1 \mathrm{~nm}$ [25]. The larger size of immobilized $\mathrm{Mo}_{6}$ clusters on GO nanosheets along with their undefined structure suggest that the $\mathrm{Mo}_{6}$ clusters are immobilized on the GO not only as single unit of each cluster, but also in form of aggregates composed of 2-7 units. Usually, these $\mathrm{Mo}_{6}$ clusters agglomerate because 
of the electrostatic attraction between anionic parts of one cluster unit and counter cationic part of another unit. Furthermore, elemental mapping of GO-Cs ${ }_{2} \mathrm{Mo}_{6} \mathrm{Br}_{8}{ }_{8}^{\mathrm{i}} \mathrm{Br}_{\mathrm{x}}^{\mathrm{a}}$ and GO-(TBA) $)_{2} \mathrm{Mo}_{6} \mathrm{Br}_{8}^{\mathrm{i}} \mathrm{Br}_{\mathrm{x}}^{\mathrm{a}}$ composites based on EDS measurements was carried out to reveal the distribution of $\mathrm{Mo}_{6}$ clusters on the GO nanosheets. Figure S4 (supporting information) shows FESEM micrographs and the corresponding elemental mapping of GO$\mathrm{Cs}_{2} \mathrm{Mo}_{6} \mathrm{Br}_{8}^{\mathrm{i}} \mathrm{Br}^{\mathrm{a}}{ }_{\mathrm{x}}$ and GO-(TBA) $)_{2} \mathrm{Mo}_{6} \mathrm{Br}_{8}^{\mathrm{i}} \mathrm{Br}^{\mathrm{a}}{ }_{\mathrm{x}}$ composites. The through and uniform distribution of cesium,

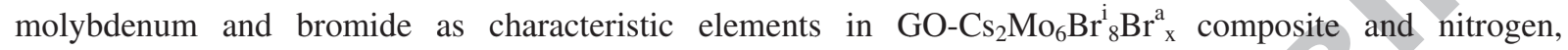
molybdenum and bromide in GO-(TBA $)_{2} \mathrm{Mo}_{6} \mathrm{Br}_{8}^{\mathrm{i}} \mathrm{Br}^{\mathrm{a}}{ }_{\mathrm{x}}$ composite indicate that $\mathrm{Mo}_{6}$ clusters are uniformly immobilized on GO nanosheets, which is very important for efficient photocatalytic activities of developed composite materials. The molybdenum content in the $\mathrm{GO}_{-} \mathrm{Cs}_{2} \mathrm{Mo}_{6} \mathrm{Br}_{8}^{\mathrm{i}} \mathrm{Br}^{\mathrm{a}} \times$ and $\mathrm{GO}-(\mathrm{TBA})_{2} \mathrm{Mo}_{6} \mathrm{Br}_{8}^{\mathrm{i}} \mathrm{Br}^{\mathrm{a}}{ }_{\mathrm{x}}$ composites was found to be 0.74 and 0.73 atomic \%, respectively, as determined by XPS analysis.
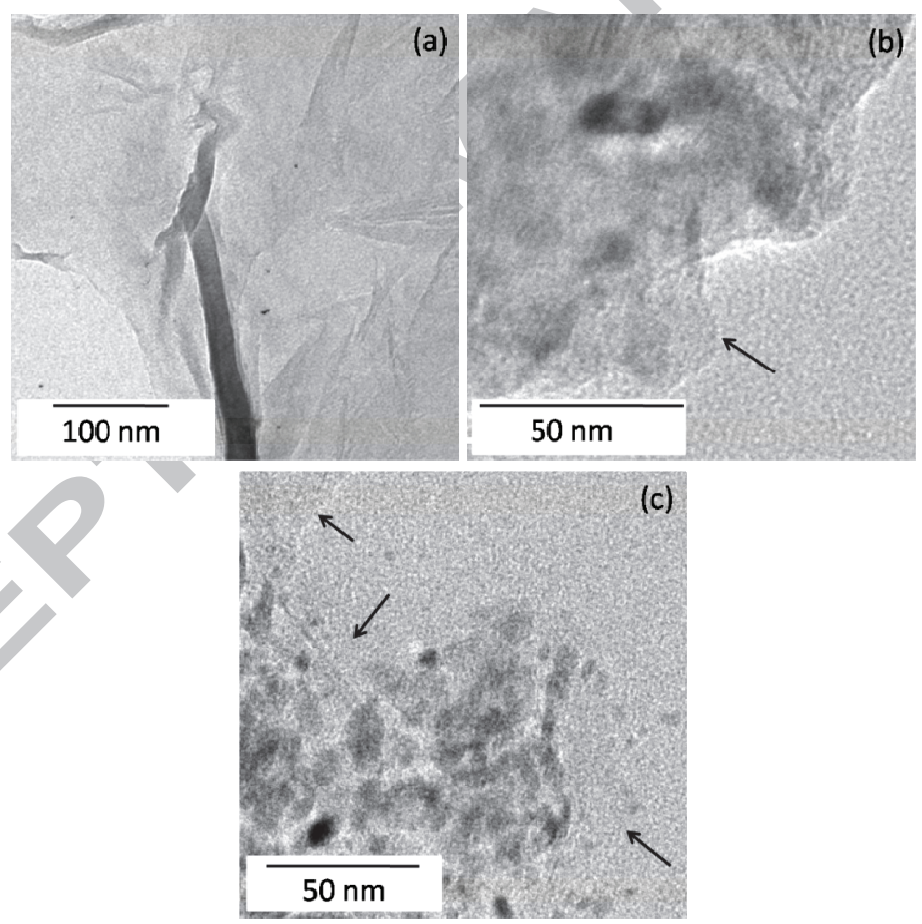

Fig. 6. HRTEM images of (a) GO nanosheets. Distribution of hexamolybdenum clusters on GO nanosheets: (b) GO$\mathrm{Cs}_{2} \mathrm{Mo}_{6} \mathrm{Br}_{8}^{\mathrm{i}} \mathrm{Br}^{\mathrm{a}}{ }_{\mathrm{x}}$ and (c) GO-(TBA) $)_{2} \mathrm{Mo}_{6} \mathrm{Br}_{8}^{\mathrm{i}} \mathrm{Br}^{\mathrm{a}}{ }_{\mathrm{x}}$ composites.

\subsection{Photocatalytic reduction of $\mathrm{CO}_{2}$}

The photocatalytic activity of the synthesized GO- $\mathrm{Cs}_{2} \mathrm{Mo}_{6} \mathrm{Br}_{8}^{\mathrm{i}} \mathrm{Br}^{\mathrm{a}}{ }_{\mathrm{x}}$ and GO-(TBA) ${ }_{2} \mathrm{Mo}_{6} \mathrm{Br}_{8}^{\mathrm{i}} \mathrm{Br}^{\mathrm{a}}{ }_{\mathrm{x}}$ composite 
materials for $\mathrm{CO}_{2}$ reduction was examined in water/DMF mixture under visible light irradiation by using 20 watt white cold LED flood light. During the photoreduction, $0.5 \mathrm{~mL}$ reaction mixture was withdrawn gradually. Then $1 \mu \mathrm{L}$ withdrawn reaction mixture was injected in a GC-FID system for quantitative estimation. The performance of the catalysts was evaluated in term of methanol $(\mathrm{MeOH})$ yield as it was the only liquid reduction product. The $\mathrm{MeOH}$ yield $\left(\mu \mathrm{mol} . \mathrm{g}^{-1}\right.$ cat.) with respect to time using $\mathrm{Cs}_{2} \mathrm{Mo}_{6} \mathrm{Br}_{8}^{\mathrm{i}} \mathrm{Br}_{6}^{\mathrm{a}}$, (TBA) ${ }_{2} \mathrm{Mo}_{6} \mathrm{Br}_{8}^{\mathrm{i}} \mathrm{Br}_{6}^{\mathrm{a}}{ }_{6}, \mathrm{GO}-\mathrm{Cs}_{2} \mathrm{Mo}_{6} \mathrm{Br}_{8}^{\mathrm{i}} \mathrm{Br}^{\mathrm{a}}{ }_{\mathrm{x}}$ and GO-(TBA) ${ }_{2} \mathrm{Mo}_{6} \mathrm{Br}_{8}^{\mathrm{i}} \mathrm{Br}^{\mathrm{a}}{ }_{\mathrm{x}}$ composite as catalyst is displayed in Figure 7. Both GO-Cs ${ }_{2} \mathrm{Mo}_{6} \mathrm{Br}_{8}^{\mathrm{i}} \mathrm{Br}_{\mathrm{x}}^{\mathrm{a}}$ and GO-(TBA) $)_{2} \mathrm{Mo}_{6} \mathrm{Br}_{8}^{\mathrm{i}} \mathrm{Br}_{\mathrm{x}}^{\mathrm{a}}$ exhibited higher photocatalytic activity as compared to GO and $\mathrm{Mo}_{6}$ clusters. Furthermore, among the two catalysts studied, GO-Cs $\mathrm{Co}_{6} \mathrm{Br}_{8}^{\mathrm{i}} \mathrm{Br}^{\mathrm{a}}{ }_{\mathrm{x}}$ was found to be superior than GO-(TBA) $)_{2} \mathrm{Mo}_{6} \mathrm{Br}_{8}^{\mathrm{i}} \mathrm{Br}_{\mathrm{x}}^{\mathrm{a}}$. After $24 \mathrm{~h}$ illumination, the yield of methanol using GO$\mathrm{Cs}_{2} \mathrm{Mo}_{6} \mathrm{Br}_{8}^{\mathrm{i}} \mathrm{Br}_{\mathrm{X}}^{\mathrm{a}}, \mathrm{GO}-(\mathrm{TBA})_{2} \mathrm{Mo}_{6} \mathrm{Br}_{8}^{\mathrm{i}} \mathrm{Br}_{\mathrm{X}}^{\mathrm{a}}$, GO, $\mathrm{Cs}_{2} \mathrm{Mo}_{6} \mathrm{Br}_{8}^{\mathrm{i}} \mathrm{Br}_{6}^{\mathrm{a}}{ }_{6}$, and $(\mathrm{TBA})_{2} \mathrm{Mo}_{6} \mathrm{Br}_{8}^{\mathrm{i}} \mathrm{Br}_{6}^{\mathrm{a}}$ as catalysts under identical experimental conditions was found to be $1644,1294,439,285$ and $238, \mu$ mol.g ${ }^{-1}$ cat, respectively with the corresponding methanol formation rate $\left(\mathrm{R}_{\mathrm{MeOH}}\right)$ of $68.5,53.9,18.2,11.8$ and $9.9 \mu$ mol.g ${ }^{-1} \mathrm{cat}^{-\mathrm{h}^{-1}}$, respectively. The turnover number (TON) and quantum yield for $\mathrm{Cs}_{2} \mathrm{Mo}_{6} \mathrm{Br}_{8}^{\mathrm{i}} \mathrm{Br}_{6}^{\mathrm{a}}{ }_{6}$ cluster were found to be 3.30 and 0.0026 , respectively, whereas, for $(\mathrm{TBA})_{2} \mathrm{Mo}_{6} \mathrm{Br}_{8}{ }_{8} \mathrm{Br}^{\mathrm{a}}{ }_{6}$ cluster the values were 2.75 and 0.0021 , respectively. The TON by using GO-Cs $\mathrm{Mo}_{6} \mathrm{Br}_{8}^{\mathrm{i}} \mathrm{Br}^{\mathrm{a}}{ }_{\mathrm{x}}$ and GO-(TBA) $)_{2} \mathrm{Mo}_{6} \mathrm{Br}_{8}^{\mathrm{i}} \mathrm{Br}^{\mathrm{a}}{ }_{\mathrm{x}}$ was found to be 19.0 , and 10.38 respectively with respect to $\mathrm{Mo}_{6}$ cluster and the quantum yields of methanol with reference to $\mathrm{Mo}_{6}$ cluster units presented in $0.1 \mathrm{~g}$ amount of catalyst were found to be 0.015 and 0.011 , respectively. The TON of methanol per mole of graphene oxide was calculated by considering the equivalent formula of $\mathrm{GO}_{\text {as }} \mathrm{C}_{6}(\mathrm{O})$, which was found to be 0.04 . The formation of methanol was further confirmed by HPLC analysis as depicted in Figures S5 and S6. For the quantitative estimation of methanol, a calibration curve was plotted by injecting an exact amount of methanol $(1 \mu \mathrm{L})$ in GC-FID (Figure S8). Then the concentration of methanol produced by photo-induced $\mathrm{CO}_{2}$ reduction was calculated by injecting $1.0 \mu \mathrm{L}$ of the final reaction solution in GC-FID and comparing the peak area with calibration curve for methanol standard. Further HPLC analysis was performed to confirm the formation of methanol as the only liquid product obtained from the photoreduction of $\mathrm{CO}_{2}$. Gaseous reaction products were analyzed by GC-FID and GC-TCD and confirmed that there was no gaseous product such as $\mathrm{H}_{2}, \mathrm{CO}, \mathrm{CH}_{4}$ formed during the photoreduction of $\mathrm{CO}_{2}$. As methanol was obtained as the only product from $\mathrm{CO}_{2}$ photoreduction under the described experimental conditions, so the catalytic selectivity (CS) 
of $\mathrm{GO}-\mathrm{Mo}_{6}$ clusters was $100 \%$.

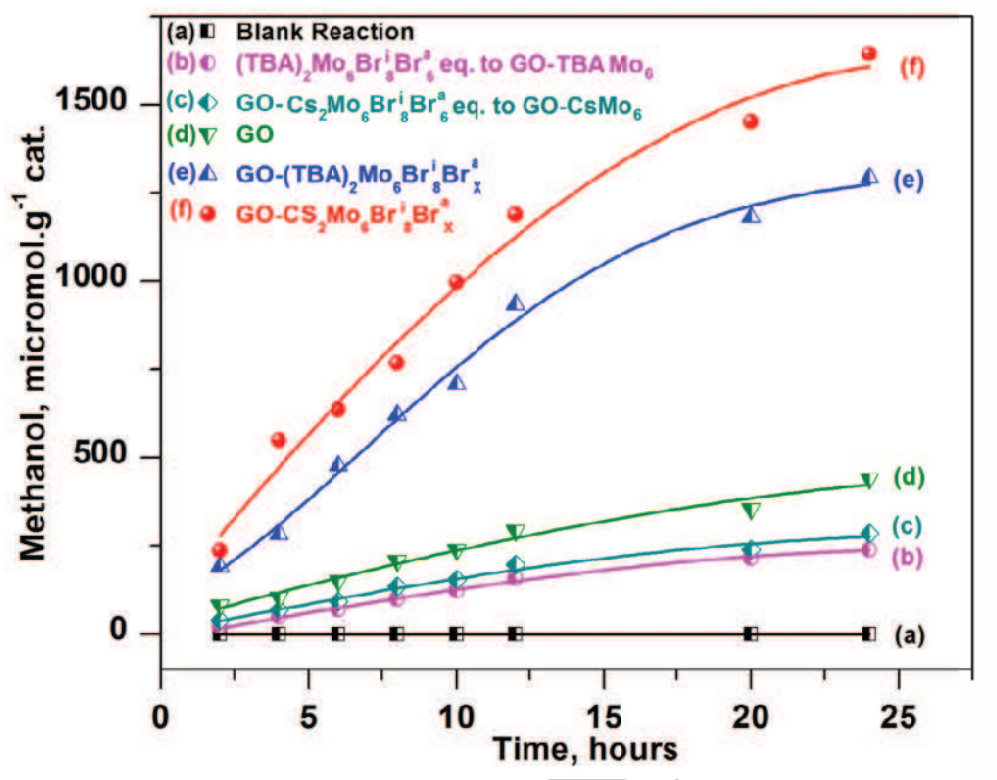

Fig 7: Methanol formation rate in (a) blank reaction, (b, c) using $(\mathrm{TBA})_{2} \mathrm{Mo}_{6} \mathrm{Br}_{8}^{\mathrm{i}} \mathrm{Br}^{\mathrm{a}}{ }_{6}$ and $\mathrm{Cs}_{2} \mathrm{Mo}_{6} \mathrm{Br}_{8}^{\mathrm{i}} \mathrm{Br}_{6}^{\mathrm{a}}{ }_{6}$ in equimolar amounts as presented in GO-composites, (d) GO, (e) GO-(TBA) ${ }_{2} \mathrm{Mo}_{6} \mathrm{Br}_{8}{ }_{8} \mathrm{Br}^{\mathrm{a}}{ }_{\mathrm{x}}$ and (f) GO$\mathrm{Cs}_{2} \mathrm{Mo}_{6} \mathrm{Br}^{\mathrm{i}}{ }_{8} \mathrm{Br}^{\mathrm{a}}{ }_{\mathrm{x}}$. catalyzed photoreduction of $\mathrm{CO}_{2}$.

Blank experiments were conducted to ensure that the product formed was due to $\mathrm{CO}_{2}$ photoreduction. The blank tests consisted of visible light irradiation in the absence of catalyst (Table 1, entry 1) and reaction in the dark with the catalyst (Table 1 , entry 2) under otherwise identical experimental conditions. An additional blank test was performed by illuminating the reaction mixture in the presence of photocatalyst by filling $\mathrm{N}_{2}$ rather than $\mathrm{CO}_{2}$ (Table 1, entry 3). In all cases, no organic product was obtained even after $24 \mathrm{~h}$ visible light exposure. 
Table: 1 Photocatalytic reduction of $\mathrm{CO}_{2}$ into methanol under controlled experimental conditions

\begin{tabular}{|c|c|c|c|c|c|}
\hline Entry & Catalyst & React. Precursor & $\begin{array}{l}\text { Visible Light } \\
\text { Illumination }\end{array}$ & $T / h$ & TON \\
\hline 1 & Nil & $\mathrm{CO}_{2}$ & Yes & 24 & - \\
\hline 2 & $\mathrm{GO}-\mathrm{Cs}_{2} \mathrm{Mo}_{6} \mathrm{Br}_{8}^{\mathrm{i}} \mathrm{Br}^{\mathrm{a}}{ }_{x}$ & $\mathrm{CO}_{2}$ & No & 24 & - \\
\hline 3 & GO- $\mathrm{Cs}_{2} \mathrm{Mo}_{6} \mathrm{Br}_{8}^{\mathrm{i}} \mathrm{Br}_{x}^{\mathrm{a}}$ & $\mathrm{N}_{2}$ & Yes & 24 & - \\
\hline 4 & $\mathrm{Cs}_{2} \mathrm{Mo}_{6} \mathrm{Br}_{8}^{\mathrm{i}} \mathrm{Br}_{6}^{\mathrm{a}}$ & $\mathrm{CO}_{2}$ & Yes & 24 & 3.30 \\
\hline 5 & $(\mathrm{TBA})_{2} \mathrm{Mo}_{6} \mathrm{Br}_{8}^{\mathrm{i}} \mathrm{Br}_{6}^{\mathrm{a}}$ & $\mathrm{CO}_{2}$ & Yes & 24 & 2.75 \\
\hline 4 & GO & $\mathrm{CO}_{2}$ & Yes & & 0.04 \\
\hline 5 & $\mathrm{GO}-\mathrm{Cs}_{2} \mathrm{Mo}_{6} \mathrm{Br}_{8}^{\mathrm{i}} \mathrm{Br}^{\mathrm{a}}{ }_{x}$ & $\mathrm{CO}_{2}$ & & 24 & 19.0 \\
\hline 6 & $\begin{array}{c}\text { GO- } \\
(\mathrm{TBA})_{2} \mathrm{Mo}_{6} \mathrm{Br}_{8}^{\mathrm{i}} \mathrm{Br}^{\mathrm{a}}{ }_{\mathrm{x}}\end{array}$ & $\mathrm{CO}_{2}$ & & 24 & 10.38 \\
\hline
\end{tabular}

Last but not least, we established the recycling of the developed heterogeneous cluster catalysts. The results of these recycling experiments are exhibited in Figure 8. As shown, both heterogeneous GO-Mo photocatalysts exhibited efficient recycling for four runs and provided almost similar yield of methanol under identical experimental conditions. These studies suggested that the developed catalysts were highly stable and the reaction was truly heterogeneous in nature.

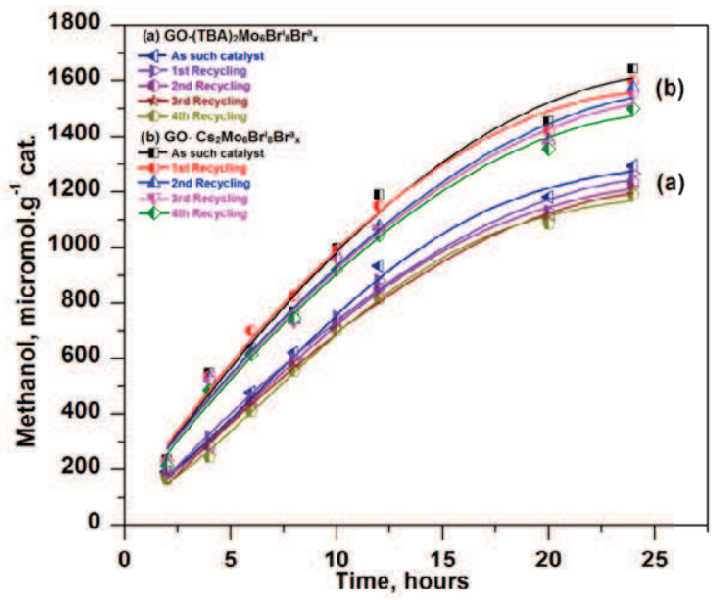

Fig: 8 Recycling experiments using (a) GO- (TBA) $)_{2} \mathrm{Mo}_{6} \mathrm{Br}_{8}^{\mathrm{i}} \mathrm{Br}^{\mathrm{a}}{ }_{\mathrm{x}}$ and (b) GO- $\mathrm{Cs}_{2} \mathrm{Mo}_{6} \mathrm{Br}_{8}^{\mathrm{i}} \mathrm{Br}^{\mathrm{a}}{ }_{\mathrm{x}}$. 
A plausible mechanism for the $\mathrm{CO}_{2}$ photoreduction to methanol using GO immobilized $\mathrm{Mo}_{6}$ clusters as catalysts on the basis of their band gap is illustrated in Figure 9. The presence of oxygen containing functionalities on GO transforms aromatic $\mathrm{sp}^{2}$ carbons into $\mathrm{sp}^{3}$ carbons and creates a network of enormous $\mathrm{sp}^{2}$ (conduction band) and $\mathrm{sp}^{3}$ carbon domains (valence band) on GO sheet. Due to presence of several conductive $\mathrm{sp}^{2}$ carbon domains and non conductive $\mathrm{sp}^{3}$ carbon containing domains on GO sheet, a band gap is created and it works like a semiconductor [51-53]. The band gap for GO was found to be $2.9 \mathrm{eV}$ in good agreement with

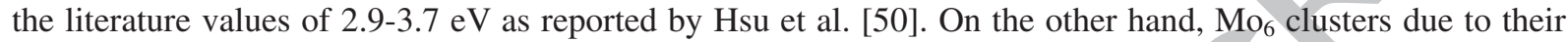
lower band gap values have good visible light absorbance; hence to improve the performance of GO in visible light, $\mathrm{Mo}_{6}$ clusters were immobilized on the surface of GO via replacement of labile bromine atoms. After absorption of visible light, $\mathrm{Mo}_{6}$ cluster was transformed to excited state $\mathrm{Mo}_{6}$ * by HOMO to LUMO transition and the excited $\mathrm{Mo}_{6} *$ transfers electron to the conduction band of GO (Fig. 9). These electrons in the conduction band of $\mathrm{GO}$ were used for the reduction of $\mathrm{CO}_{2}$ to give methanol [54-56]. The positively charged $\mathrm{Mo}_{6}{ }^{+}$cluster gets electron from valence band of $\mathrm{GO}$ and transforms back into its original $\left(\mathrm{Mo}_{6}\right)$ state. Water splitting at the valance band of GO possibly provides necessary electrons and protons for the reduction of $\mathrm{CO}_{2}$ to methanol. Furthermore, due to the better charge mobility and higher surface area, GO improves the catalytic performance synergistically [57-59].

$6 \mathrm{Mo}_{6}$ cluster $+h v \rightarrow 6 \mathrm{Mo}_{6} *$ cluster (excited state)

$6 \mathrm{Mo}_{6} *$ cluster $($ excited state $)+\mathrm{GO} \rightarrow 6 \mathrm{e}^{-}(\mathrm{GO}$ conduction band $)+6 \mathrm{Mo}_{6}{ }^{+}$cluster

$6 \mathrm{e}^{-}\left(\mathrm{GO}\right.$ conduction band) $+\mathrm{CO}_{2}+6 \mathrm{H}^{+} \rightarrow \mathrm{CH}_{3} \mathrm{OH}+\mathrm{H}_{2} \mathrm{O}$

$3 \mathrm{H}_{2} \mathrm{O} \rightarrow 6 \mathrm{H}^{+}+6 \mathrm{e}^{-}+3 / 2 \mathrm{O}_{2}$

$6 \mathrm{Mo}_{6}^{+}$cluster $+6 \mathrm{e}^{-} \rightarrow 6 \mathrm{Mo}_{6}$ cluster

Overall reaction $\mathrm{CO}_{2}+6 \mathrm{H}^{+}+6 \mathrm{e}^{-} \rightarrow \mathrm{CH}_{3} \mathrm{OH}+\mathrm{H}_{2} \mathrm{O}$ 


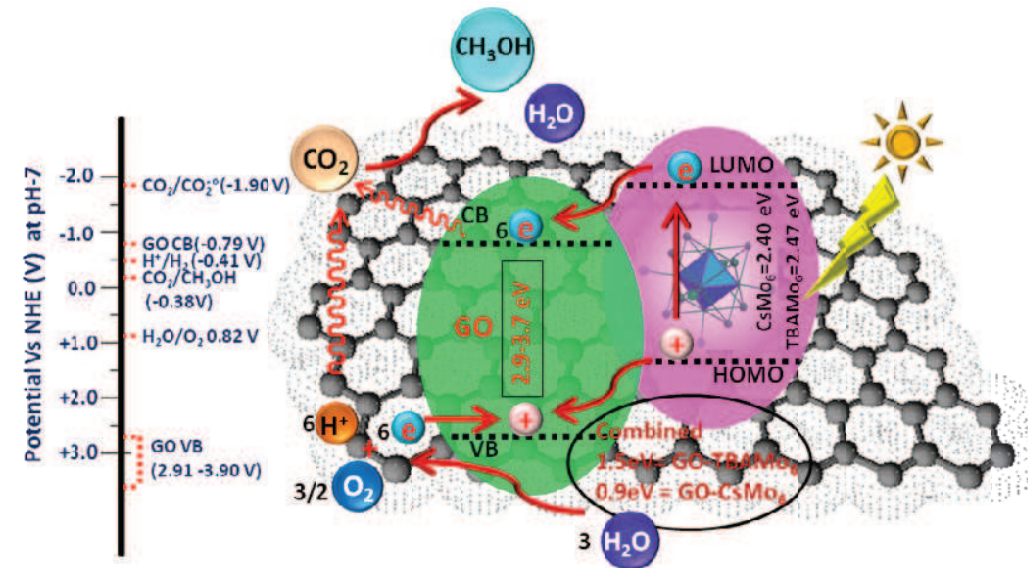

Fig. 9 Plausible mechanism of photoreduction of $\mathrm{CO}_{2}$ into methanol catalyzed by GO-hexamolybdenum composite

\subsection{Conclusion}

Hexamolybdenum cluster compounds i.e. $\mathrm{Cs}_{2} \mathrm{Mo}_{6} \mathrm{Br}_{8}^{\mathrm{i}} \mathrm{Br}^{\mathrm{a}}{ }_{x}$ and $(\mathrm{TBA})_{2} \mathrm{Mo}_{6} \mathrm{Br}_{8}^{\mathrm{i}}{ }_{8} \mathrm{Br}^{\mathrm{a}}{ }_{x}$ were immobilized on GO nanosheets and the resulting composites were used for the photocatalytic reduction of $\mathrm{CO}_{2}$ to methanol under visible light irradiation without adding any sacrificial agent. Owing to the wide band gap, GO alone does not provide excitation in the visible. The $\mathrm{Mo}_{6}$ units located on the surface of $\mathrm{GO}$ act as visible light absorbers and facilitate the transfer of electrons to GO conduction band. After $24 \mathrm{~h}$ of visible light illumination, the yield of

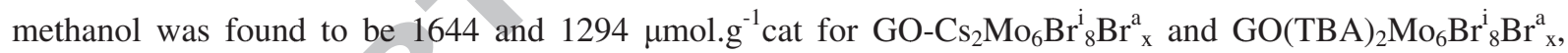
respectively. These values are much higher than GO alone $\left(439 \wedge \mathrm{mol.g}{ }^{-1} \mathrm{cat}\right)$. However, the facile recovery, efficient recycling and no need of sacrificial donors such as triethylamine make the developed methodology superior and more advantageous for converting $\mathrm{CO}_{2}$ to high value chemicals.

\section{Acknowledgement}

We kindly acknowledge Director, CSIR-IIP for his permission to publish these results. PK and HPM are thankful to CSIR and UGC, New Delhi, respectively for providing research fellowship. Analytical department of the Institute is kindly acknowledged for providing support in analysis. DST, New Delhi is kindly acknowledged for providing financial support. 


\section{Notes and references}

[1] D. R. Dreyer, S. Park, C. W. Bielawski and R. S. Ruoff, Chem. Soc. Rev. 39 (2010) 228-240.

[2] V. Georgakilas, M. Otyepka, A. B. Bourlinos, V. Chandra, N. Kim, K. C. Kemp, P. Hobza, R. Zboril and K. S. Kim, Chem. Rev. 112 (2012) 6156-6214.

[3] S. Navalon, A. Dhakshinamoorthy, M. Alvaro and H. Garcia, Chem. Rev. 114 (2014) 6179-6212.

[4] D. R. Dreyer, A. D. Todd and C. W. Bielawski, Chem. Soc. Rev. 43 (2014) 5288-5301.

[5] D. R. Dreyer, H. P. Jia and C. W. Bielawski, Angew. Chem. Int. Ed. 49 (2010) 6813-6816.

[6] H. P. Jia, D. R. Dreyer and C. W. Bielawski, Adv. Synth. Catal. 353 (2011) 528-532.

[7] D. R. Dreyer, H. P. Jia, A. D. Todd, J. Geng and C. W. Bielawski, Org. Biomol. Chem. 9 (2011) $7292-7295$.

[8] S. Verma, H. P. Mungse, N. Kumar, S. Choudhary, S. L. Jain, B. Sain and O. P. Khatri, Chem. Commun. 47 (2011) 12673-12675.

[9] A. Dhakshinamoorthy, M. Alvaro, M. Puche, V. Fornes, and H. Garcia, Chem. Cat. Chem. 4 (2012) 2026-2030.

[10] D. R. Dreyer, K. A. Jarvis, J. P. Ferreira and C. W. Bielawski, Polym. Chem. 3 (2012) 757-766.

[11] C. Su, M. Acik, K. Takai, J. Lu, S. Hao, Y. Zheng, P. Wu, Q. Bao, T. Enoki, Y. J. Chabal and K. P. Loh, Nat. Commun. 3 (2012) 1298.

[12] S. Kim, S. Zhou, Y. Hu, M. Acik, Y. J. Chabal, C. Berger, W. Heer, A. Bongiorno and E. Riedo, Nat. Mater. 11 (2012) 544-549.

[13] S. Choudhary, H. P. Mungse and O. P. Khatri, Chem. Asian J. 8 (2013) 2070-2078.

[14] H. P. Mungse, N. Bhakuni, D. Tripathi, O. P. Sharma, B. Sain and O. P. Khatri, J. Phys. Org. Chem. 27 (2014) 944-951.

[15] Y. Li, W. Gao, L. Ci, C. Wang and P. M. Ajayan, Carbon 48 (2010) 1124-1130.

[16] G. M. Scheuermann, L. Rumi, P. Steurer, W. Bannwarth and R. Mulhaupt, J. Am. Chem. Soc.131 (2009) 8262-8270.

[17] J. Huang, L. Zhang, B. Chen, N. Ji, F. Chen, Y. Zhang and Z. Zhang, Nanoscale 2 (2010) $2733-2738$. 
[18] H. P. Mungse, S. Verma, N. Kumar, B. Sain and O. P. Khatri, J. Mater. Chem. 22 (2012) 5427-5433.

[19] C. Yuan, W. Chen and L. Yan, J. Mater. Chem., 22 (2012) 7456-7460.

[20] P. V. Kamat, J. Phys. Chem. Lett. 1 (2010) 520-527.

[21] G. Moon, H. Kim, Y. Shin and W. Choi, RSC Adv. 2 (2012) 2205-2207.

[22] G. Williams and P. V. Kamat, Langmuir 25 (2009) 13869-13873.

[23] A. W. Maverick, J. S. Najdzionek, D. Mackenzie, D. G. Nocera and H. B. Gray, J. Am. Chem. Soc. 105 (1983) 1878-1882.

[24] A. Barras, M. R. Das, R. R. Devarapalli, M. V. Shelke, S. Cordier, S. Szunerits and R. Boukherroub, Appl. Catal. B 130-131 (2013) 270-276.

[25] F. Grasset, F. Dorson, S. Cordier, Y. Molard, C. Perrin, A. M. Marie, T. Sasaki, H. Haneda, Y. Bando and M. Mortier, Adv. Mater. 20 (2008) 143-148.

[26] S. Cordier, F. Grasset, Y. Molard, M. Amela-Cortes, R. Boukherroub, S. Ravaine, M. Mortier, N. Ohashi, N. Saito and H. Haneda, J. Inorg. Organomet. Polym. Mater. 25 (2015) 189-204.

[27] P. Kumar, S. Kumar, S. Cordier, S. Paofai, R. Boukherroub and S. L. Jain, RSC Adv. 4 (2014) 10420-10423.

[28] G. A. Olah, Angew. Chem. Int. Ed. 52 (2013) 104-107.

[29] M. Aresta, Carbon dioxide reduction and use as a chemical feedstock, Tolman, W.B., Ed.; WileyVCH: Weinheim, Germany, 2006, 1-41.

[30] V. P. Indrakanti, J. D. Kubicki, and H. H. Schobert, Energy Environ. Sci. 2 (2009) 745-758.

[31] P. D. Tran, L. H. Wong, J. Barber and J. S. C. Loo, Energy Environ. Sci. 5 (2012) 5902.

[32] Halmann M. M.; Steinberg M. Greenhouse Gas Carbon Dioxide Mitigation Science and Technology, Lewis Publishers, Boca Raton, Florida. 1999.

[33] Y. Izumi, Coord. Chem. Rev. 257 (2013) 171-186.

[34] S. N. Habisreutinger, L. S. Mende, and J. K. Stolarczyk, Angew. Chem. Int. Ed. 52 (2013) $7372-$ 7408.

[35] A. J. Cowan and J. R. Durrant, Chem. Soc. Rev. 42 (2013) 2281-2293.

[36] A. J. Morris, G. J. Meyer and E. Fujita, Acc. Chem. Res. 42 (2009) 1983-1994. 
[37] A. Inagakia and M. Akita, Coord. Chem. Rev. 254 (2010) 1220-1239.

[38] R. Reithmeier, C. Bruckmeier and B. Rieger, Catalysts 2 (2012) 544-571.

[39] H. Takeda and O. Ishitani, Coord. Chem. Rev. 254 (2010) 346-354.

[40] X. T. Zhou, H. B. Ji and X. J. Huang, Molecules 17 (2012) 1149-1158.

[41] M. E. Ragoussi, J. Malig, G. Katsukis, B. Butz, E. Spiecker, G. Torre de la, T. Torres and D. M. Guldi, Angew. Chem. Int. Ed. 51 (2012) 6421-6425.

[42] K. Kirakci, S. Cordier, C. Perrin, Z. Anorg. Allg. Chem. 631 (2005) 411-416.

[43] H. Schaefer, H. G. Schnering, J. Tillack, F. Kuhnen, H. Woehrle, H. Baumann, Z. Anorg. Allg. Chem. 353 (1967) 281-310.

[44] D. Yang, A. Velamakanni, G. Bozoklu, S. Park, M. Stoller, R. Piner, S. Stankovich, I. Jung, D. Field, C. A. Ventrice Jr. and R. S. Ruoff, Carbon 47 (2009) 145-152.

[45] O. Akhavan, ACS Nano 4 (2010) 4174-4180.

[46] S. Ababou-Girard, S. Cordier, B. Fabre, Y. Molard and C. Perrin, ChemPhysChem 8 (2007) 20862090.

[47] T. Aubert, F. Cabello-Hurtado, M.-A. Esnault, C. Neaime, D. Lebret-Chauvel, S. Jeanne, P. Pellen, C. Roiland, L. Le Polles, N. Saito, K. Kimoto, H. Haneda, N. Ohashi, F. Grasset, and S. Cordier, J. Phys. Chem. C 117 (2013) 20154-20163.

[48] T. Aubert, A. Burel, M.-A. Esnault, S. Cordier, F. Grasset, and F. Cabello-Hurtado, J. Hazard. Mater. 219 (2012) 111-118.

[49] O. A. Efremova, M. A. Shestopalov, N. A. Chirtsova, A. I. Smolentsev, Y. V. Mironov, N. Kitamura, K. A. Brylev and A. J. Sutherland, Dalton Trans. 43 (2014) 6021-6025.

[50] H. C. Hsu, I. Shown, H. Y. Wei, Y. C. Chang, H. Y. Du, Y. G. Lin, C. A. Tseng, C. H. Wang, L. C. Chen, Y. C. Lin, and K. H. Chen, Nanoscale 5 (2013) 262-268.

[51] K. P. Loh, Q. Bao, G. Eda, and M. Chhowalla, Nature Chem. 2 (2010) 1015-1024.

[52] F. Bonaccorso, Z. Sun, T. Hasan and A. C. Ferrari, Nature Photon. 4 (2010) 611-622.

[53] G. Eda, C. Mattevi, H. Yamaguchi, H. Kim, and M. Chhowalla, J. Phys. Chem. C 113 (2009) 1576815771. 
[54] P. Kumar, A. Kumar, B. Sreedhar, B. Sain, S. S. Ray, and S. L. Jain, Chem. Eur. J. 20 (2014) 61546161.

[55] P. Kumar, A. Bansiwal, A. Bansiwal, N. Labhsetwar and S. L. Jain, Green Chem. 17 (2015) 16051609.

[56] P. Kumar, B. Sain and S. L. Jain, J. Mater. Chem. A 2 (2014) 11246-11253.

[57] G. hee Moon, Y. Park, W. Kim, W. Choi, Carbon 49 (2011) 3454-3462.

[58] Y. T. Liang, B. K. Vijayan, K. A. Gray and M. C. Hersam, Nano Lett. 11 (2011) 2865-2870.

[59] G. Jiang, Z. Lin, C. Chen, L. Zhu, Q. Chang, N. Wang, W. Wei, H. Tang, Carbon 49 (2011) 26932701. 